\title{
Justyna Prusinowska
}

\section{GROMADKARZE LITEWSCY I MAZURSCY WOBEC ZABOBONÓW, „BAJEK” I „RZECZY BRZYDKICH”1}

Słowa kluczowe:

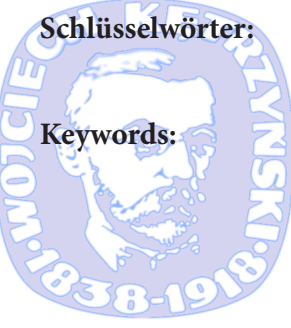

gromadkarze, ruch gromadkarski, Mazurzy, Litwini, Mała Litwa, folklor, przesądy

der Surinkimininker, die Gemeinschaftsbewegung, Masuren, Litauer, Kleinlitauen, Folklore, abergläubischen

members of the Fellowship Movément, Fellowship Movement, Masurians, Lithuanians, Lithuania Minor, folklore, superstitions

Kto wejrzy głębiej, by zobaczyć, co ukrywa wnętrze, ten przekona się o sprzeczności między forma a treścia oraz prześledzi nici - jedne wiodące $z$ wciąż panującego pogaństwa, inne prowadzace do katolicyzmu, a także splot obydwu. Groża one zduszeniem pobożności i istoty wiary protestanckiej. Najpierw powiedzmy kilka słów o zabobonach.

Friedrich Salomo Oldenberg, Przyczynki do poznania Mazur

W dotychczasowych publikacjach, poświęconych litewskiemu i mazurskiemu ruchowi gromadkarskiemu, centralne miejsce zajmuje omówienie jego genezy i rozwoju ${ }^{2}$. O poglądach, a szczególnie postawie jego uczestników wobec ludowości

1 Artykuł powstał w ramach projektu badawczego „Modernybès ir tradicijos sampyna: surinkimininkų judejjimas Mažojoje Lietuvoje” („Splot nowoczesności i tradycji: ruch gromadkarski w Małej Litwie”) finansowanego przez Radę Naukową Litwy (Lietuvos mokslo taryba), nr umowy S-MOD-17-10.

2 W. Gaigalat, Die evangelische Gemeinschaftsbewegung unter den preußischen Litauern. Geschichtliches und Gegenwärtiges von..., Königsberg 1904; W. Gaigalatis, Ewangeliszki Surinkimai Lietuwoje. Isztyrinējimai apie jû Pradžia, Augima bey dabartinị Buwị, Priekule 1905; F. Lej(y)k-Różyński, Zrzeszenia gromadkarskie wśród Mazurów, zamieszkałych na Mazowszu Pruskim, Nadrenii i Westfalii, Przegląd Ewangelicki, 1937, nr 8, ss. 70-71, nr 9, ss. 80-81, nr 10, ss. 88-89, nr 11, ss. 101-102, nr 12, ss. 111-114; E. Sukertowa-Biedrawina, Zagadnienie gromadkarstwa na Mazurach (Przyczynek do dziejów „gromadek”), Przegląd Zachodni, 1950, nr 9-10, ss. 272-283; R. Otello, Ruch gromadkarski w Prusach Wschodnich w latach 1848-1914, Komunikaty Mazursko-Warmińskie, 1976, nr 3, ss. 307-328; G. Jasiński, U źródet gromadkarstwa. O grupie „świętych” na Mazurach, Komunikaty Mazursko-Warmińskie, 1996, nr 3, ss. 369-377; G. Jasiński, Pomiędzy sektą a Kościołem. Gromadkarze litewscy i mazurscy w XIX wieku (do 1885 roku), Komunikaty Mazursko-Warmińskie, 1999, nr 1, ss. 17-42; G. Jasiński, Neopietyzm 
i reliktów pogaństwa, pisze się niewiele, a to z tej przyczyny, że brakuje bezpośrednich źródeł mogących tę lukę wypełnić. Jak pisze Grzegorz Jasiński, przynajmniej do poł. lat 80-tych XIX wieku, na „ich [gromadkarzy - J.P.] działalność i poglądy patrzymy oczami innych, najczęściej duchownych Kościoła krajowego (unijnego), nauczycieli, czasami przedstawicieli władz administracyjnych"3 a i w późniejszym okresie sami zainteresowani zabierają głos głównie w sprawie dokonujących się w ich świecie przemian i rozłamów. Wyrażenie „patrzymy oczami innych” można w dużej mierze potraktować dosłownie, gdyż obserwatorom udało się opisać prawie wyłącznie manifestowaną na zewnątrz postawę czy też odmienny strój gromadkarzy. W związku z tym, należy się zastanowić, czy ten wystawiony na widok publiczny obraz był prawdziwy, czy też może skonstruowany sztucznie, wyłącznie dla zaspokojenia ciekawości „innych”.

We wszystkich opracowaniach, które w jakimś stopniu dotykają omawianego problemu, uwypukla się te same informacje odnośnie prowadzących skrajnie ascetyczny tryb życia litewskich klimkénai (także: klimkiškiai), grupy skupionej początkowo wokół Klimkusa Grigelaitisa (1750-1825), a istniejącej do $1939 \mathrm{roku}^{4}$ albo tez zarysowuje utrwalony przed II wojną światową obraz gromadkarzy w ogóle. Autorem jednej z takich właśnie, pełniejszych charakterystyk jest pochodzący z gromadkarskiej rodziny Fryderyk Lej(y)k-Różyński. Pod koniec lat 30-tych XX wieku pisał on, że:

członkowie zrzeszenia wstrzymywać się muszą od używania napojów alkoholowych, a w zupełności od palenia tytoniu. [...] Zabawy wszelkiego rodzaju nie mają u nich miejsca. Są oni przeciwnikami wszelkich rozrywek światowych jak: sportu, tańca, gimnastyki, teatru, kina, bawienia się w kawiarniach, restauracjach itd. Odzież ich jest skromna. Mężczyźni chodzą przeważnie bez kołnierzyka i krawatu, zwykle z czarnym półkoszulkiem i chusteczką na szyi. Kobiety - „nawrócone” - nie noszą kapelusza, lecz skromne ciemne chustki. Noszenie jedwabnych pończoch, eleganckiego obuwia, pięknych, do figury robionych sukien uważają za grzech, ponieważ to nie godzi się z cnotą chrześcijańskiej pokory. Włosy noszą długie, gładko czesane. Mężczyźni są prawie wszyscy goleni. Brodę noszą tylko jednostki, wąsów - nikt. Ograniczanie urodzeń, stosowanie środków zapobiegawczych, uważa się za wielki grzech. Jeszcze niedawno unikano bez wy-

a postawy narodowe. Ruch gromadkarski na Mazurach w XIX i XX w. (do 1956). Czesść I, Gdański Rocznik Ewangelicki, 2014, vol. VIII, ss. 108-134; G. Jasiński, Apie liuteronybès diferenciaciją Rytų Prūsijoje. Pastabos dèl surinkimu Mozūrijoje XVIII a. pabaigoje - XIX a. pradžioje, Acta Historica Universitatis Klaipedensis: Kristijono Donelaičio epochos kultürinès inovacijos, nr XXVI, 2013, ss. 135-147.

3 G. Jasiński, Pomiędzy sektą a Kościołem, s. 17.

4 A. Žemaitaitis, klimkiškiai, klimkènai, Senasis surinkimas, w: Mažosios Lietuvos Enciklopedija, t. 2, red. V. Pèteraitis, Z. Zinkevičius, M. Purvinas, Vilnius 2003, s. 233. 
jątku lekarzy. Zwracano się z modlitwą do Boga, Pana życia i śmierci, o uzdrowienie chorego. Obecnie pod tym względem spostrzega się pewien postęp. Nawet zamożni ludzie dzieciom nie dawali żadnego wyższego wykształcenia. Posyłanie synów na studia akademickie uchodziło za pychę, którą zwykle Pan Bóg karze. W ostatnich czasach jednak i co do tego nastąpiła pewna zmiana. ${ }^{5}$

Darius Petkūnas i Algirdas Žemaitaitis podsumowali z kolei dostępne w różnych źródłach wiadomości charakteryzujące gromadkarzy i zamknęli prezentowaną przez nich postawę w zwięzłej definicji:

Gromadkarze musieli być pobożni, pokorni, zamknięci w sobie, trzeźwi, skromni, pracowici, szlachetni, rzetelni, uczciwi, wierni Bogu i władzy. Zasadami pobożności i wysokiej moralności gromadkarzy były modlitwa, ubóstwo, post, miłość bliźniego, miłosierdzie, prawość, moralność, samokontrola, cierpliwość. ${ }^{6}$

W obliczu powyższego wydawać by się mogło, ze w życiu gromadek nie było miejsca dla wiary w zabobony, które traktowano przecież na równi z pozostałymi reliktami pogaństwa i, co za tym idzie, jak i inne „bałwochwalstwa”, niestrudzenie zwalczano. Przemawiać mógłby za tym również skąpy materiał folklorystyczny zebrany w granicach niegdysiejszej Małej Litwy, na której bardzo silnie zakorzeniony był protestantyzm, a gromadkarze pojawili się już w II ćwierci XVIII wieku, by na początku wieku XX stanowić ok. 45\% mieszkańców całego obszaru ${ }^{7}$ Protestantyzm przecież, jak pisze Dalia Kisielunaitė „nie wpuszczał do kościoła niczego, czego nie było w Piśmie Świętym i unikał teatralności”8, a wiele wskazywać mogłoby na to, że szczelności granicy sacrum - profanum strzegli przede wszystkim członkowie gromadek.

Gromadkarze byli społecznością niezmiernie skrytą i zamkniętą na „obcych”. Ostatni świadkowie życia na wsi w Małej Litwie przed II wojną światową, przechowali ich w pamięci jako wspólnotę wciąż jeszcze niezwykle hermetyczną. Rzadko mieli oni przekraczać granice swoich zagród, nieczęsto odwiedzali sąsiadów, zazwyczaj wyłącznie podczas najważniejszych świąt rodzinnych lub kościelnych (wesela czy też Wielkanocy), ich dzieci nie spacerowały po wsi bez potrzeby i nie zawierały przyjaźni z rówieśnikami, a więcej swobody zyskiwały dopiero po konfir-

$5 \quad$ F. Lej(y)k-Różyński, op. cit., nr 11, s. 101.

6 D. Petkūnas, A. Žemaitaitis, Surinkimininkai, maldininkai, w: Mažosios Lietuvos Enciklopedija, t. 4, red. V. Bagdonavičius, D. Valentukevičienè, V. Kaltenis, Vilnius 2009, s. 359.

Ibidem, ss. 359-360.

8 D. Kisielunaitè, Senujų baltiškuju papročiu pėdsakai lietuvininkų šventèse, w: Lietuvininkų kalba. Mažosios Lietuvos tautosaka. Mažosios Lietuvos etnografija. Mokslinès konferencijos pranešimai, Kaunas 1994, s. 76. 
macji, a więc od ok. 14 roku życia ${ }^{9}$. W granicach mikroświata gromadkarzy znajdował się oprócz domostwa i miejsca pracy jedynie kościól, domy zgromadzeń oraz cmentarz, a dodatkowo, tę i tak już wąską przestrzeń, ograniczały, wspomniane już powyżej, liczne surowe reguły.

Niedostępność i ascetyczność członków gromadek utrudniały i, co może być zaskoczeniem, nadal jeszcze stoją na przeszkodzie badaczom, chcącym rozpoznać w sposób dostateczny nie tylko przez nich samych eksponowane aspekty życia, ale też m.in. kwestię wiary $\mathrm{w}$ magię, przesądy i inne zjawiska sprzeczne $\mathrm{z}$ nauką płynącą z Biblii. By móc jednak przyjrzeć się bliżej temu nieprzebadanemu dotąd obszarowi, omówić należy, z jednej strony, stosunek gromadkarzy do folkloru, ludowości i dziedzictwa kulturowego w ogóle, z drugiej zaś - zastanowić, na ile ich zapatrywania na ten konkretny, nierzadko istotny przecież, składnik codzienności, miały szansę przedostać się poza granice tego ruchu i zostać zarejestrowanymi przez obserwatorów z zewnątrz.

Mała Litwa jest tym regionem, którego folklorem zainteresowano się bardzo wcześnie. Już w 1747 roku trzy oryginalne pieśni (miłosną młodych, humorystyczną młodych i weselną), wraz z tłumaczeniem $/$ na język niemiecki, opublikowal Wo dziele Betrachtung der littauischen Sprache (które zaczęto drukować już dwa lata wcześniej), urodzony w Kattenau (obecnie Заветы w obwodzie kaliningradzkim), Philipp Ruhig (1675-1749). Pierwszy osobny zbiór pieśni z tego obszaru, a jednocześnie pierwszy zbiór pieśni litewskich w ogóle - Dainos oder Littauische Volkslieder, ukazał się z kolei w roku $1825^{10}$, a wydał go urodzony również w Litwie Pruskiej, we wsi Karwaiten (zasypanej w 1779 roku przez ruchome piaski) na Mierzei Kurońskiej, Ludwig Rhesa (1776-1840). Jeszcze w 2 poł. XIX wieku repertuar pieśni był z całą pewnością imponujący i niezmiernie różnorodny, a świadczy o tym głównie zbiór pieśni (542 jednostki) zgromadzonych przez Viliusa Kalvaitisa, uzupełniony przezeń o teksty ogłoszone lub zebrane wcześniej przez innych autorów (łącznie - ok. 800 tekstów) i wydany w Tylży w 1905 roku ${ }^{11}$.

Urodzony w okolicach Ragnety Kalvaitis (1848-1914), przede wszystkim zagorzały działacz na rzecz ochrony języka litewskiego wobec postępującej za czasów jego działalności germanizacji był jednym z pierwszych folklorystów działających na Małej Litwie. To właśnie on, jak pisał Kazys Grigas, „wyorał jako zbieracz folklo-

9 Informacje pozyskane w trakcie ekspedycji zorganizowanej w ramach projektu badawczego „Modernybès ir tradicijos sampyna: surinkimininkų judejimas Mažojoje Lietuvoje” („Splot nowoczesności i tradycji: ruch gromadkarski w Małej Litwie") w dn. 23.08.2017. Informatorka: Ruth Lydia Tetmeier, zamężna Babonienė (Rūta Babonienè), ur. 02.11.1929 w Vidkiemis, gm. Smalininkai, obecnie zamieszkała w Viešvilè. Materiał przechowuje LKI (Lietuvių kalbos institutas).

10 L.J. Rhesa, Dainos oder Litthauische Volkslieder gesammelt, übersetzt und mit gegenüberstehendem Urtext herausgegeben von..., Königsberg 1825.

11 Prusijos Lietuviu dainos. Surinko ir pridedamas anas per Rèzą, Nesselmann'ą, Dr. Sauerweinią bei kitus rinktas arba sutaisytas dainas išleido savo paties kašta Vilius Kalvaitis, Tilžè 1905. 
ru i wydawca w Małej Litwie bodajże najszerszą skibę"12. W ciągu 25 miesięcy, pomiędzy 1888 a 1894 rokiem, odwiedził Kalvaitis ponad 90 parafii w Małej Litwie ${ }^{13}$, ale $\mathrm{w}$ domach gromadkarzy, pomimo iż pochodził $\mathrm{z}$ tego samego regionu, znał język i obowiązujące zwyczaje, nie był miłym gościem. Ich mieszkańcy na jego słowa: „ja nie tylko opowieści, albo, dokładniej mówiąc, wypadki ukazywania się dusz, laum, a[i]twarów, nazwy wsi, ale i piosenki zbieram" ${ }^{14}$, żądali, by wyszedł, bo przecież „Boga mamy czcić, a nie takimi rzeczami się zajmować” ${ }^{15}$. Bardzo znamienne w tej wypowiedzi jest to, jak szczególny stosunek mieli gromadkarze właśnie do ludowej pieśni. Nie tak bardzo oburzało ich wspomnienie duchów domowych, istot mitycznych, jak właśnie piosenki, a więc jednego z fundamentalnych elementów kultury ludowej. Pieśń ludowa była w życiu mieszkańców wsi obecna zawsze, zarówno podczas uroczystości dorocznych, rodzinnych, pracy na gospodarstwie, jak i najbardziej nawet błahych codziennych zajęć, ale dla gromadkarzy „litewskie śpiewanie bardziej jest wstrętne, aniżeli pogańskie działania, szerzy «żmudzką» beźbożność, itd." ${ }^{16}$, i dlatego też postanowiono je zagłuszyć - przede wszystkim pełnym natchnienia śpiewem religijnym i modlitwą.

Każda z wymienionych powyżej publikacji, a przede wszystkim żbiór pieśni Kalvaitisa jest znakomitym dowodem na to, że znano w tym zakątku Europy wiele utworów frywolnych, obrazoburczych oraz nawiązujących do tradycji pogańskiej. Wykonywanie takich piosenek było z pewnością przez przedstawicieli ruchu gromadkarskiego traktowane jako jawne i głośne przyznanie się do kontynuowania bałwochwalczych zwyczajów czyli postępowanie wbrew nauce Kościoła. Żaden inny gatunek folkloru nie jest tak eksponowany, nośny i wpływowy, jak pieśń ludowa, a więc to ona, jako pierwsza, stać się musiała celem pietystów. Lina Petrošiené, choć nie dostrzegła obecności gromadkarzy w Małej Litwie (pisze o negatywnym oddziaływaniu wiary luterańskiej na folklor tego obszaru, a jednocześnie fakt ten argumentuje wypowiedzią archiwalną raczej jednoznacznie wskazującą konkretnie na omawiany ruch religijny: „Litwini Pruscy byli zamknięci. [...] u Litwinów Pruskich był porządek [...] Śpiewać, tańczyć tu nikt nie pozwalał. Wszystko przewinienie, grzech" ${ }^{17}$ ), porównując repertuar pieśni ludowych zebranych w wieku XIX

12 K. Grigas, Ką išsaugojo Vilius Kalvaitis, w: Prūsijos lietuvių dainos. Surinko Vilius Kalvaitis [faksimilinis leidinys], red. K. Aleksynas, Vilnius 1998, s. VII.

13 W. Kalwaitis, Lietuwiszku Wardų Klètele su 15000 wardų... Surinko 1888-1894 m. ir iszleido W. Kalwai tis, Tilžè 1910, s. IV.

14 Ištraukos iš Viliaus Kalvaičio „Dienknygu“. Parengė I. Žilienè, w: Tautosakos darbai, 1999, t. XI(XVIII), s. 175 .

15 Ibidem.

16 Klaipédiškiu dainos. Surinko Jons Pakalniškis [A. Bruožis], Vilnius 1908, s. 4.

17 Savickienė Ieva, ur. 1909, Priekulè, w: KUTRF [Klaipėdos universiteto Humanitarinių mokslų fakulteto folkloro laboratorijos tautosakos rankraštyno fonoteka] 2, 1992, cyt. za: Lina Petrošienè, Klaipédos krašto XX a. antrosios pusés liaudies dainu pateikèjai ir kai kurios jų dainu melodiju ypatybès, w: Vakarų Lietuvos muzika (I). Žurnalo „Tiltai“ priedas nr. 7. Mokslo darbai, red. S. Vaitekūnas, Klaipèda 2001, s. 28. 
i na początku kolejnego stulecia oraz w 2 poł. XX wieku, zauważa, że pod względem gatunkowym bardzo się on uszczuplił, zapomniane zostały pieśni kalendarzowe i towarzyszące pracy (m.in. praniu, mieleniu, orce - choć nie można wykluczyć, że takie akurat pieśni, w obliczu postępu cywilizacyjnego i mechanizacji rolnictwa, po prostu przestały być aktualne), a zaczęły przeważać w nim, choć i tak, już nie $\mathrm{w}$ tak imponującej liczbie, te towarzyszące życiu rodzinnemu oraz weselne, miłosne, wojskowe, historyczne i rybackie ${ }^{18}$. Jakiejkolwiek by jednak treści utwory te nie były, chłopi, którzy przystąpili do gromadkarzy, zaniechali, przynajmniej publicznego, jak wykażemy poniżej, ich wykonywania, bo świadczyłoby to o braku nawrócenia, a więc uniemożliwiło zbawienie. Strach towarzyszący tej wizji musiał być zaś ogromny. Dowodzi tego dobitnie relacja innego folklorysty, Jonasa Balysa (1909-2011).

Balys zbierał literaturę ustną na Mierzei Kurońskiej na pocz. XX stulecia, ale borykał się z identycznymi, jak i Kalvaitis, problemami. Dla ich zobrazowania opisał szczegółowo swą stoczoną w roku 1936 walkę o zdobycie ludowej pieśni, a historię tę warto przytoczyć w całości:

Wczasując się w Preili, podjąłem próbę odszukania i zapisania folkloru rybackiego. Dowiedziałem się, że pieśni zna starzec Adomas Naujokas, mający ponad 80 l. Jednakże jego domownicy zaczęli się wymawiać, że ze starego nic już dobrego nie ma, nadszedł już jego czas, by umrzeć, ciężko już z nim się rozmówić, niczego już nie pamięta. Tak i nie pozwolili mi go zobaczyć, wskazali tylko, że litewskie i kurońskie pieśni zna Martynas Ercnieks. Teraz szukam Martynasa. Jego nazwisko wskazuje, że będzie to Kuron. Przedwieczorem znajduję w domu. Obiecuje zaśpiewać następnego dnia wieczorem. Jednakże przyszedłszy następnego dnia i on zaczął zmieniać zdanie, słyszy, nie będzie już śpiewać: staremu nieładnie, sąsiedzi śmiać się będą, żona skarci. Ledwo przekonałem, że wszystko to nieważne. Jednak w domu śpiewać nie może, do mojego pokoju w hotelu również iść nie chce, tak więc, postanowiliśmy spotkać się na wydmach, gdzie nikt nie usłyszy i nie zobaczy. Idziemy za wieś na wydmy. Opowiada, jak wydmy były sosenkami porośnięte, gdzie łosie chodzą pić, gdzie po drugiej stronie Zatoki jest „W grunt poszedłsze miasto” i próbuje śpiewać. Zaśpiewał litewską piosenkę „Wysokie góry równe łąki” i kurońską „Wchodzę na wysokie góry”. Zna jeszcze jedną bardzo piękną „chłopską” [lit. būriška] piosenkę, ale teraz nijak nie może sobie przypomnieć. To typowy rybak, łysy 72 letni starzec, urodzony i wychowany w Melnragé, wdowiec i w biedzie chowany syn rybaka. Rodzice w domu rozmawiali po kurońsku. Zna kuroński, „chłopski” i niemiecki. Czytać i pisać umie

18 Lina Petrošienè, op. cit., s. 30. 
słabo. Służył w niemieckiej marynarce wojennej (obie ręce wytatuowane), był nawet w Baltimore. Dawniej, gdy spotykali się na połów lub w karczmie przy piwie, wyśpiewywali litewskie i kurońskie pieśni - wiele ich znał, ale teraz trudno sobie przypomnieć, wszystko plączą nuty religijnych pieśni. Jego żona, widać, wielka "gromadkarka”, bardzo nie lubi świeckich pieśni, a on sam przyznaje, „boję się, by nie strofowali z góry”. Teraz zrozumiałem, dlaczego trzeba było iść śpiewać na wydmy i po części inne moje niepowodzenia. Np., płynąc łodzią zagadałem się z rybaczką. Zagadnięta przeze mnie kobieta w podeszłym wieku Skiraitienè z Pervalki przyznała się, że zna „chłopskie” pieśni, zna je jeszcze jej sąsiadka Juodjurgienè (wszystko prawdziwe litewskie nazwiska), ale gdy umówionego dnia dotarłem do Pervalki, ani jedna nie dała się namówić na śpiewanie, choć jedna przyznała, że przed kilku laty śpiewała już jednemu panu. Oto kto wytępił nasze litewskie pieśni - gromadkarze ze swoimi naukami i pieśniami. Teraz wiem, dlaczego niektóre kobiety, zapytane, czy nie znają litewskich pieśni, natychmiast potwierdzają, że zawsze po litewsku i z litewskich książek śpiewają, ale zapytane, czy nie znają „litewskich świeckich pieśni”, z dumą odpowiadają, że u nich takich rzeczy nie ma, tak jakby była to rzecz niecna i grzeszna, i chwała Panu, ze zostały zapomniane, albo, nawet jeśli wciąż znają, nie mają odwagi ust otworzyć. Oczywiście, nie można tutaj zapomnieć o wpływie agitacji niemieckiej. ${ }^{19}$

Relacja Balysa, jednego z najznakomitszych litewskich folklorystów, wskazuje na bardzo szkodliwy, niszczycielski wpływ ruchu gromadkarskiego na dziedzictwo kulturowe omawianego regionu ${ }^{20}$. Żadna z informacji podanych przez badacza nie jest zbędna, ani nawet mało istotna, wszystkie one składają się na wielowarstwowy obraz społeczeństwa - w tym konkretnym przypadku - społeczności rybaków zamieszkujących Mierzeję Kurońską, która, obawiając się gniewu Bożego, ukrywa przed obcym i innym swą prawdziwą tożsamość. Co ważne, członkowie tej społeczności, w której spotkać można także i „wielkich gromadkarzy”, a więc, jak można przypuszczać, osoby bardzo, a może i przesadnie pobożne, doskonale orientują się, kto zna i śpiewa ludowe pieśni. Wykonywanie ich nie mogło więc w tym czasie należeć do rzadkości, choć z drugiej strony, należy pamiętać o znacznym już wówczas okrojeniu repertuaru i skażeniu go przez pieśni religijne. Nie można nie odnotować, że Ercnieks, oprócz piosenek, przekazał Balysowi także i podanie o zapadłym mieście, bo to z kolei świadczy o tym, że folklor na omawianym terenie był w ogóle wciąż jeszcze żywy. Spustoszenie w nim poczynione było już jednak w tym czasie

19 Iš Mažosios Lietuvos tautosakos / Folk-lore from Lithuania Minor. Surinko J. Banaitis, J. Bruožis, D. Jagomastas, E. Jankutè, A. Vilmantienè ir kt., red. J. Balys, w: Tautosakos darbai III, Kaunas 1937, s. 8.

20 Podobne zresztą zjawisko zaistniało na znacznym obszarze dzisiejszej Łotwy, na którym z kolei już od roku 1729 działali herrnhuci. 
ogromne, choć dodać trzeba, że ucierpiał nie tylko repertuar pieśni ludowych, ale $\mathrm{i}$ inne obszary kultury ludowej. Vytautas Kavolis podaje, że z winy gromadkarzy prawie wyginęły tradycyjne tańce okręgu Kłajpedy ${ }^{21}$, Jonas Basanavičius zauważył, że na zamieszkiwanych przez nich wsiach zniknęły nie tylko bajki i pieśni, ale i barwny strój ludowy, a podobny los spotkał w krótkim czasie dawne, kultywowane przez wieki tradycje ${ }^{22}$. Opisująca rok mazurski Emilia Sukertowa-Biedrawina, fragmenty dotyczące Zapustów i zwyczajów żniwnych, uzupełniła na marginesie o drobne uwagi dotyczące wpływu, jakie wywierali nań właśnie gromadkarze:

Na Zapusty trzeba tańczyć (a nie tańczą w ogóle tzw. gromadkarze, sekta religijna, która ma tę dobrą stronę, że nie tylko dba o dobre obyczaje i cnoty, ale pielęgnuje mowę ojczystą w praktykach religijnych), należy jeździć saniami, aby się len udał $[\ldots] .^{23}$

W drodze do domu śpiewają żniwiarze pieśni świeckie i żartobliwe. (Pobożni „gromadkarze” jeno nie lubią żartów, a pieśni świeckich wesołych nie uznają). ${ }^{24}$

Wzmianki te świadczyć mogą o tym, że członkowie gromádek aktywnie uczestniczyliw życiu wsi, być może kultywowali dawne tradycje, ale nie dopełniali rytuałów, stojących w sprzeczności z ich przekonaniami lub też mogących wywołać zgorszenie u innych. Takie ich zachowanie sprawiało $\mathrm{z}$ kolei, że pielegnowane od pokoleń zwyczaje zatracały swe pierwotne sensy, a z krajobrazu kulturowego znikały stopniowo kolejne elementy.

Z dostępnego materiału wynika, że gromadkarze zamykali się nie tylko przed „nie nawróconymi” członkami społeczności, obcymi, ale i najbliższą rodziną. Ujawnienie dopuszczenia się "grzechu” doprowadzić by mogło do podziałów w rodzinie, a nawet ostracyzmu ${ }^{25}$. Za znakomity przykład posłużyć mogą wspomnienia filozofa i pisarza Vydūnasa (właśc. Wilhelm Storost, 1868-1953) związane z matką, Marie Aschmons (1836-1907), której wuj, Jakob Aschmons (1800-1862), brat ojca, był znanym nie tylko w Małej Litwie kaznodzieją gromadkarskim i autorem pieśni. Jak zapisał Vydūnas, jego matka, pomimo iż pochodziła $\mathrm{z}$ rodziny głęboko religijnej, wciąż jeszcze miała wiele szacunku dla ludowej tradycji. W jego pamięci przechował się m.in. taki obrazek:

${ }_{21}$ Za: Ištraukos iš Viliaus Kalvaičio „Dienknygǔ“, s. 163.

22 J. Basanavičius, Iš krikščionijos santykiu su senovès lietuvių tikyba ir kultūra. (Prie studijos „Lietuvių kryžiai archaiologijos šviesoje”), Vilnius 1912, ss. 55-57.

${ }^{23}$ „Rok mazurski” Emilii Sukertowej. Tekst opracował, wstępem, komentarzem i przypisami opatrzył Zbigniew Anculewicz, Mrągowskie Studia Humanistyczne. Pismo poświęcone historii i literaturze w regionie mazurskim, 2004/2005, t. 6-7, s. 366.

${ }_{24}$ Ibidem, s. 372. Zob. też R. Otello, Obchody żniwne na Mazurach, Komunikaty Mazursko-Warmińskie, 1978, nr 2, ss. 274-275.

25 Por. G. Jasiński, Pomiędzy sektą a Kościołem, s. 27. 
[p]rzędąc lub wykonując jakąś inną pracę, cicho śpiewała religijne, a niekiedy i ludowe pieśni. Jak tylko jednak Vydūnas lub inne z jej dzieci wchodziło do jej pokoju, nagle przerywała swoją pieśń lub nuconą piosenkę. Vydūnas bardzo często widywał ją siedzącą z książkami w ręce. Były to religijne pisma, Ewangelia, a niekiedy i wydawany przez Friedricha Kurschaita „Keleiwis”26.

W innym miejscu można przeczytać:

Wraca Vilius ze szkoły nieco wcześniej niż zwykle i słyszy, że z kuchni, gdzie matka przygotowuje obiad dla rodziny, dobiega cicha litewska pieśń. Otwiera chłopiec drzwi i słucha. A matka cicho śpiewa. Zobaczywszy syna peszy się i cichnie. Rzuca się Vilius ku matce, obejmuje ją i błaga: - Mamusiu, pośpiewajjeszcze. - Nie mogę, - to grzech. I gdyby brat twego ojczulka, kaznodzieja Jakub żył i dowiedział się o tym, doświadczyłabym wielu nieprzyjemności. Vilius jednak matki nie odstępuje - Chociaż kawałeczek, chociaż ciszej... - Dobrze, mówi matka. Ale nikt nie ma o tym wiedzieć. Niech to będzie tajemnica naszej dwójki. Dochował Vilius tajemnicy. A jego matka, gdy nadarzyła się okazja, gdy nikt nie słuchał, śpiewała synowi pieśni swego dzieciństwa przyniesione z Minge i Naujakiemis ${ }^{27}$.

Sytuacja, w jakiej Wilhelm zastał swoją matkę, a więc śpiewanie przy pracy, stawia pod znakiem zapytania skuteczność metody radzenia sobie z grzesznymi myślami. Jedna z najważniejszych ambasadorek Małej Litwy, a szczególnie okręgu Kłajpedy, Ieva Simonaityte (Ewa Simoneit, 1897-1978), w powieści Los rodziny Šimoniai z Aukštujai (Aukštujų Šimoniu likimas), wydanej w roku 1935, zawarła bowiem pewną myśl: „Rodzina nie może istnieć bez pracy, złych myśli można się nabawić" ${ }^{28}$. Obrazek naszkicowany przez Vydūnasa sugeruje, że mogło być wręcz odwrotnie. Ani modlitwa, ani natłok codziennych obowiązków, nie były w stanie rozwiać czy też odsunąć grzesznych myśli, co więcej - praca, szczególnie ta wykonywana w samotności, sprzyjała nawet „bałwochwalstwu”. Mieli jednak gromadkarze inny jeszcze sposób na radzenie sobie z pokusami, a mianowicie modlitwę. We wspomnieniach Jokūbasa Pukisa (1895-1993) znaleźć można fragment poświęcony ojcu, Martinasowi (1864-1941), zanim ten jeszcze stał się gorliwym członkiem gromadki i kaznodzieją:

26 A. Merkelis, Ǐ̌ Vydūno vaikystès ir jaunystès, Aidai, 1953, nr 4, ss. 159-162,

http://www.aidai.eu/index.php?option=com_content\&view=article\&id=5724:pa\&catid=345:4-balandis\&Itemid=387 [dostęp: 03.11.2018].

27 B. Aleknavičius, Vydūno pédomis, cz. 1, 2013, http://mokslolietuva.lt/2013/02/vyduno-pedomis/ [dostęp: 03.11.2018].

28 I. Simonaitytè, Aukštujų Šimonių likimas. Romanas, Vilnius 1976, s. 258. 
Jeśli chcesz zdrowe ciało i zdrową duszę mieć, musisz powstrzymać się od szkodliwych działań. Jeśli nie zdołasz, módl się, gdyż modlitwa jest niczym miecz o dwóch ostrzach tnących! ${ }^{29}$

Cennych wiadomości na temat charakteru pobożnych mieszkańców omawianego obszaru w okresie późniejszym, dostarcza niewielka objętościowo praca pt. Podania, zebrane $w$ rejonie szyłokarczemskim (Padavimai, surinkti Šilutés rajone), stanowiąca podsumowanie wyprawy naukowej podjętej przez studentki z obecnego Uniwersytetu Wileńskiego, I. Fieldmanaitė i S. Bakaitė w roku 1969. Opracowanie to powstało więc w czasie, gdy, co podkreśliły zresztą same autorki już we wstępie: „[r]egionaliści z Szyłokarczmy, folkloru, można powiedzieć, właściwie nie zbierają"30, a to, jak można się domyślać, na skutek m.in. trudnego położenia politycznego, w jakim znalazł się ten obszar za czasów radzieckich oraz małej jego atrakcyjności przez wzgląd na wcześniejszą germanizację i silne wpływy pietystyczne.

Autorki zamierzały pozyskać materiał od mieszkanców urodzonych w okolicach Szyłokarczmy jeszcze przed wojną, a więc dysponujących, z założenia, unikatową wiedzą na temat miejscowego folkloru. Jak się jednak okazało, „miejscowych można policzyć na palcach” ${ }^{31}$. W Rusi [Rusnè] spotkały Jurgineitisa, który „zaśpiewał pieśni, poopowiadał baśnie"32, w Pakalnè - Žemutaitisa, który opowiedział kilka baśni, m.in. o kaukach ${ }^{33}$, ale, jak relacjonowali sąsiedzi, „jeśli człowiek mu się spodoba [...], może dużo opowiedzieć" ${ }^{34}$, w miasteczku Saugos spotkały jeszcze dawnych mieszkańców, dysponujących niemałą wiedzą, przykładowo Tendysa, ale „inni «o bajkach» nie bardzo chcą mówić" ${ }^{35}$.

Studentki zawarły w pracy tylko jedenaście podań, w tym cztery warianty historii powstania jeziora Krokų lanka (mimochodem napomknęły również o „pięknych zagadkach”36 oraz zwyczaju próbnych zaręczyn ${ }^{37}$ ), ale ważne informacje przekazują też pozornie lakoniczne notki na temat informatorów. Nie wspomniano w nich, co prawda, o jakichkolwiek powiązaniach rozmówców z ruchem gromadkarskim, ale niektóre komentarze mogłyby na to wskazywać. Już powyższa informacja o mieszkańcach Saugos, którzy miejscowy folklor nazywają „bajka-

${ }_{29}$ J. Pukis, Abipus rubežiaus. II $d$. Web: http://www.silaine.lt/2009/2009-10-06/Pukio_prisiminimai_ IId-19.htm [dostęp: 03.11.2018].

30 I. Fieldmanaitè, S. Bakaitè, Padavimai, surinkti Šilutès rajone, Vilnius 1969, VUB RS, sygn. F213-110, s. 1.

31 Ibidem, s. 4.

32 Ibidem, s. 2.

33 Ibidem, s. 3.

34 Ibidem, s. 3.

35 Ibidem, s. 4.

${ }^{36}$ Ibidem, s. 8.

${ }^{37}$ Ibidem, s. 4. 
mi", a co za tym idzie, nie chcą o nim opowiadać jest bardzo wymowna. Kristupas Endrys, również z Saugos, ale urodzony we wsi Dreverna nad Zatoką Kurońską w roku 1897, byłby opowiedział więcej, ale „wówczas nie mógł sobie przypomnieć, a oprócz tego, cały tydzień pracował, czasu nie miał" ${ }^{38}$, wspomniany Žemutaitis dzielił się swą wiedzą wyłącznie z wybranymi rozmówcami, a urodzona w okolicy Saugos w 1888 roku Marija Berg zbyła studentki słowami: „Ot, mój mąż [...], ten dużo wiedział. A ja, co, siedziałam cały czas w jednym miejscu i nic nie wiem. I co wiedziałam, wszystko zapomniałam" ${ }^{39}$. Ostrożne zachowanie rozmówców, milczenie lub niechęć do rozmowy, określanie podań mianem „bajek”, wynikać mogło $\mathrm{z}$ ich głębokich przekonań religijnych.

Niektórzy informatorzy Fieldmanaite i Bakaitè nazywali siebie Kurońskimi Litwinami lub Pruskimi Litwinami, część z nich słabo znała język litewski, w ich domach rozbrzmiewał wyłącznie niemiecki. Urodzona w roku 1909 Gelžienè ze wsi Petreliai niedaleko Saugos, scharakteryzowana została następująco: „Typowa Niemka okręgu Kłajpedy. Bardzo szanuje książki, naukę. Mieszka dostatnio, schludnie - nawet bardzo schludnie. Bardzo ceni poczucie humoru, ale sama jest powściąliwa, chociaż uprzejma, gościnna." "Owa „powściągliwość w okazywaniu uczuć, a szczególnie radości, to kolejna przecież, obok nieufności i zamknięcia na obcych, cecha gromadkarzy. Wszystkie one w znacznym stopniu utrudniły studentkom zbieranie materiałów, choć z drugiej strony, stanowią ważne świadectwo tego, jak trwałe były zachowania zaszczepione niegdyś przez głęboko religijnych członków zamkniętych, wiejskich społeczności.

Dużo później, bo w latach 90-tych XX wieku, omawiany obszar badała pod względem etnograficznym Rūta Grumadaitè. Po przeprowadzeniu wywiadów z mieszkańcami okręgu Kłajpedy, podsumowała zdobytą wiedzę słowami, które wciąż jeszcze odnieść by można było do członków gromadek: „Prawdziwi mieszkańcy tego kraju wyraźnie przechowali ukształtowany na przestrzeni stuleci $\mathrm{w}$ trudnych warunkach historycznych powściągliwy, nieufny, a nawet surowy charakter, to bardzo specyficzny typ narodowy. Niełatwo z nim obcować, a i wiara nie toleruje śpiewu, radości. Jednym słowem, bez osobistych relacji, bliska znajomość $\mathrm{z}$ rozmówcami, zdobycie większej liczby pewnych, oryginalnych jednostek folklo$\mathrm{ru}$, jest bardzo skomplikowane"41.

W dniach 20-27 sierpnia 2017 roku, w ramach projektu „Splot nowoczesności i tradycji: ruch gromadkarski w Małej Litwie” („Modernybės ir tradicijos sampyna:

38 Ibidem, s. 19.

39 Ibidem, s. 21.

40 Ibidem, s. 14.

${ }^{41}$ R. Grumadaitè, Klaipėdos krašto tautosakinè situacija (Pagal paskutiniujų ekspedicijų medžiaga), w: Lietuvininku kalba. Mažosios Lietuvos tautosaka. Mažosios Lietuvos etnografija. Mokslinių konferenciju pranešimai, Kaunas [1994], s. 35. 
surinkimininkų judejjimas Mažojoje Lietuvoje”), zorganizowano ekspedycję naukową w okolice Szyłokarczmy (Šilutè), Pojegów (Pagègiai), Smolnik (Smalininkai), Wieszwil (Viešvilè) i Rusi (Rusnè). Także podczas tego objazdu, pytani o wiarę w przesądy protestanci, nierzadko potomkowie i powinowaci członków gromadek, reagowali niekiedy nerwowo, wręcz z oburzeniem ${ }^{42}$. Okazuje się, że pomimo upływu lat, granica, jaką niegdyś przeprowadził Kościół pomiędzy swoimi i obcymi wciąż istnieje. Choć obecnie zapytania o zabobony i inne relikty kultury ludowej nie sieją już pośród rozmówców tak dużego zgorszenia, to jednak wciąż silny jest opór przed przyznaniem się do wiedzy na temat zjawisk przez religię potępianych. Nadal byłoby to równoznaczne z przyznaniem się do grzechu i opowiedzeniem po „złej stronie” - obcych, pogan, zwolenników i kontynuatorów tradycji ludowej33.

Właściwie każda z przywołanych dotąd wypowiedzi obserwatorów lub uczestników ruchu gromadkarskiego, akcentuje pewne niezmiernie złożone i interesujące zjawisko: znani z gorliwej, a nawet fanatycznej niekiedy (opisywano zdarzające się podczas zgromadzeń zachowania ekstatycźne ${ }^{44}$ ) religijności i bogobojności gromadkarze, odsłaniali w grupie ,nawróconych", w rodzinie, a niekiedy dopiero w samotności, pozornie tylko wymazane $z$ ich dusz, naznaczone pewną pierwotnością, zakamarki. Głębokie przeżywanie wiary mogło w pewnej liczbie przypadków, być może żnacznej, służyć wyłącznie za pewną gęstą zasłonę, skrywającą świat, w którym elementy wiary pogańskiej i chrześcijańskiej nie stały ze sobą w sprzeczności, ale dopełniały się wzajemnie. Znamienne jest to, że zasłona ta nie opadła nawet wówczas, gdy ruch w formie zorganizowanej przestał istnieć. Przykład rozmówców Kalvaitisa, Balysa, Vydūnasa oraz członków ekspedycji naukowych różnych lat, pokazuje, że w świecie gromadkarzy zawsze było dość miejsca także dla elementów kultury ludowej, choć na forum publicznym uważano je za grzech i tępiono. Nie raz podnoszono głosy, że religijność gromadkarzy była wyłącznie na pokaz, w codziennym zaś życiu nie zawsze postępowali oni właściwie, byli fałszywi i obłudni ${ }^{45}$. Może to jednak wynikać $\mathrm{z}$ faktu, że tempo zmian na wsi litewskiej i mazurskiej było zbyt szybkie, a chłopi chcący wkroczyć do świata „kultury” uczynili to bezrefleksyjnie i bez większego przygotowania. Ich dotychczasowe życie w sposób drastyczny odróżniało się od tego, jakie proponowali pietyści i zniwelowanie różnic nie mogło być w krótkim czasie możliwe. Zapewne z tego powodu jedynie skrzętnie ukrywano

42 Informacje pozyskane w trakcie ekspedycji zorganizowanej w ramach projektu badawczego „Modernybės ir tradicijos sampyna: surinkimininkų judejimas Mažojoje Lietuvoje” („Splot nowoczesności i tradycji: ruch gromadkarski w Małej Litwie") w dn. 22.08.2017. Informatorka: Gertrud Septinus, zamężna Liutkienè (Gertrūda Liutkienè), ur. 26.10.1932 w Šilmeižiai, gm. Šilutė, obecnie zamieszkała w Šilutė. Materiał przechowuje LKI (Lietuvių kalbos institutas).

43 Por. J. Tilvikas, Tarp religinių, kultūrinių, socialinių priešpriešų: lietuvininkų liaudies medicina XIXXX a. pirmoje puseje, Logos, 2016, nr 89, ss. 189-190.

44 G. Jasiński, op. cit., s. 41.

45 Ibidem, s. 35. 
lub poddawano daleko idącym modyfikacjom elementy zbyt krzykliwe, kłócące się z nowym wizerunkiem i prawdami nie do końca rozpoznanej wiary.

Informacje o wróżbach, zaklęciach czy magii stosowanej przez członków ruchu gromadkarskiego są rzadkie, aczkolwiek wiemy już, że fakt ten nie musi być wcale świadectwem ich nieobecności, ale właśnie umiejętnego maskowania. W międzywojniu, jak w odniesieniu do Mazur pisze Grzegorz Jasiński, ale stwierdzeniem tym objąć można także omawiany wycinek Litwy, „zmniejszył się [...] zasób lokalnych obyczajów, określanych wcześniej przez władze kościelne jako zabobony, zresztą część z nich usunęła postępująca germanizacja. Jednak wiele z nich wciąż egzystowało, nie wywołując u nikogo konfliktu sumienia, widziano w nich (jak i wcześniej) wzmocnienie wiary. Z kolei niektóre nieortodoksyjne zwyczaje kościelne, powodujące dawniej irytację władz w Królewcu (klękanie, żegnanie się, składanie ofiar w intencji), teraz były akceptowane. Nadal dostrzegało się silne pietystyczne akcenty w religijności mazurskiej”46. Przykłady tzw. „zabobonów nabożnych”, które "najczęściej wiązały się z pracami gospodarskimi, świętami kościelnymi, chrztem, ślubem, pogrzebem, istniał zwyczaj «kupowania» od Boga pomyślności, w zamian za obiecane sumy, inne dotyczyły usuwania «złego» z ludzi i zwierzą" ${ }^{\prime 47}$, wymienił i pokrótce omówił Jasiński w innym miejscu ${ }^{48}$, a na podstawie obserwacji zachowań we własnej rodzinie, zjawisko to opisał m.in. pisarz Herbert Somplatzki.

Jak pisze ten ostatni, wiarę jego babci, Luizy Burdenski, urodzonej w 1882 roku (zm. 1975) w Piwnicach Wielkich na Mazurach,

zasilało wiele źródeł, z których kilka należy z pewnością zaliczyć do przesądów. Była więc na przykład zdania, że przez zaklęcia [...] można było tak zaczarować krowę, by odebrać jej mleko i mogła ona nawet zachorować. Mogą istnieć ludzie o takiej sile - twierdziła - że są w stanie przemienić się w ropuchy i sprzymierzyć z diabłem. Przeciw takim „carom” pomóc może tylko „przeżegnacz”, tak zwane „zażegnanie”, co też sama czasem praktykowała. Przy czym na zakończenie czyniła zawsze rękami znak krzyża; gest, którego rdzeń zapożyczony

46 G. Jasiński, Neopietyzm a postawy narodowe, s. 122.

47 G. Jasiński, Kościół ewangelicki na Mazurach w XIX wieku (1817-1914), Olsztyn 2003, ss. 254-262.

48 Ibidem, osobny podrozdział Zabobony $i$ „zwyczaje katolickie”. Również Friedrich Salomo Oldenberg poświęcił w swoim sprawozdaniu z wizytacji wsi mazurskich wiele miejsca właśnie zabobonom w dziale Zabobony i katolicyzm (F.S. Oldenberg, Przyczynki do poznania Mazur. Sprawozdanie dla Centralnego Komitetu do Spraw Misji Wewnętrznej, przeł. M. Szymańska-Jasińska, oprac. i wstęp G. Jasiński, Warszawa 2000, ss. 84-92). Najważniejszym informatorem Oldenberga był gromadkarz Jan Jenczio (1797-1884) ze wsi Markowskie w powiecie oleckim, który, w odpowiedzi na prowadzoną przez siebie „działalność umoralniającą”, obejmującą m.in. rugowanie przywar, postrzegany był początkowo przez miejscowych chłopów jako „opętany przez Belzebuba” (Ibidem, s. 81). „Gdy występowałem z żarliwością przeciwko zabobonom - relacjonował Jenczio - jakieś 30, 40 lat temu - wtedy w całych Markowskich zapanował gniew i jeśli nad wsią przeszła burza lub gradobicie, mówiono: «Jenczio temu winien». Zostałem wyklęty i przeklęty" (Ibidem, ss. 81-82). 
został z wiary katolickiej. [...] Również przy bólu głowy moja babcia praktykowała „zażegnanie” i położenie rąk na bolące miejsce. Podczas tej ceremonii mruczała niezrozumiałe słowa i stale kończyła znakiem krzyża. ${ }^{49}$

Jednocześnie pisze Somplatzki, że babcia Luiza „miała w sobie jednak tak ogromną żarliwość, która musiała przerażać nowoczesnych niedowiarków" ${ }^{50}$. Zdaniem autora „był to pewien rodzaj archaicznego oddania się wierze, do której wliczało się także grzeszne zachowanie", przykładowo - picie alkoholu ${ }^{51}$.

Słowa użyte przez Somplatzkiego na określenie religijności Luizy Burdenski (nie ma informacji, by należała ona do gromadki, lecz jest to wielce prawdopodobne ${ }^{52}$ ), w rzeczywistości doskonale oddają charakter religijności gromadkarzy w ogóle.

Jurkūniškiai, znacząca grupa gromadkarzy, oskarżali wspomnianych wcześniej klimkènai o powierzchowność i skupienie na budowaniu efektownego wizerunku zewnętrznego, zamiast na prawdziwej, relacji z Bogiem i duchowości ${ }^{53}$. Friedrich Salomo Oldenberg, który w roku 1865 udał się w kilkutygodniową służbową podróż po Mazurach (był pracownikiem Centralnego Komitetu do Spraw Misji Wewnętrznej Niemieckiego Kościoła Ewangelickiego), sporządził z niej obszerne sprawozdanie, opatrzone tytułem Zur Kunde Masurens ${ }^{54}$, zawierające bardzo istotne dla naszych rozważań spostrzeżenia. Odnotował on mianowicie, że

[p]obożność Mazura jest przeważnie niedojrzała lub też zatrzymała się w początkowym stadium rozwoju. Składają się na nią raczej na pół prymitywne pojęcia i instynkty niż jasne doświadczenie. Brak jej zrozumienia i etyczne-

49 H. Somplatzki, Wiara mojej babci-sprawozdanie z zatopionego świata, w: Ewangelicy na Warmii i Mazurach. Dzieje i współczesność. Praca zbiorowa, red. E. Kruk, Olsztyn 2001, ss. 53-54. Jak pisze Jasiński, „sami chłopi odróżniali «żegnanie» od «zamawiania». Pierwsze opierało się na modlitwie szczególnie «bogobojnej osoby», czyniącej bez zapłaty dobro innym, zaś to drugie - na magicznych formułkach (czary i używanie w nich imienia Bożego było uznawane za grzech)”. G. Jasiński, Kościół ewangelicki, s. 256. Czynienie znaku krzyża uważali zaś mazurscy ewangelicy za „lokalny obyczaj ewangelicki”, a nie „katolicki zwyczaj”. Ibidem, s. 259.

50 H. Somplatzki, op. cit., s. 54.

51 Ibidem.

52 Somplatzki podaje, że babcia czytała „mazurską Biblię”, a po wojnie, gdy kościół w Wielbarku zamknięto, uczestniczyła w nabożeństwach w prywatnych mieszkaniach - „to były proste uroczystości, a ich głównymi cechami były wspólne modlitwy i śpiewanie pieśni kościelnych” (H. Somplatzki, op. cit., s. 54). Dodatkowo, miejsce narodzin Luizy Burdenski, Piwnice Wielkie, leży w powiecie szczycieńskim, w gminie Wielbark. M.in. w Wielbarku na pocz. XIX w. działała grupa „świętych”, pod koniec zaś tego stulecia w Szczytnie i Wielbarku liczba gromadkarzy szybko rosła, a w 1897 odbyło się w powiecie szczycieńskim 160 zebrań gromadkarskich. R. Otello, Ruch gromadkarski $w$ Prusach Wschodnich, ss. 480, 485-486. W Szczytnie wydawano również prasę gromadkarską, „Trąbę Ewangelijną” (1912-1913) oraz „Głos Ewangelijny” (1925 lub 1926-1939). R. Otello, „Głos Ewangelijny” (1925-1939), Komunikaty Mazursko-Warmińskie, 1977, nr 1, ss. 81-90.

53 R. Otello, Ruch gromadkarski w Prusach Wschodnich, s. 314.

54 Rękopis przechowywany jest w Centralnym Archiwum Ewangelickim w Berlinie (Das Evangelische Zentralarchiv in Berlin), syg. EZA 7/19141, k. 152r-238r. 
go przyswojenia religijnych treści. Bez oporu toleruje zaprzeczenie religijności - bezbożność, i to w najbardziej ostrych przejawach. Nie wzburza jej ta wewnętrzna, aczkolwiek przykryta zewnętrzną formą, sprzeczność. Życie Mazura rozszczepione jest między poszukiwaniem zbawienia duszy i władzą zmysłowych, surowych mocy natury, które wciąż trzymają się go, przywiązane niczym niewolniczym łańcuchem. Do dzisiaj ani Kościół, ani szkoła nie uwolniły go od ich uroku. Jak słyszy się z ust owego ludu: jest to wzdychanie kreatury, która tęskni za zbawieniem.

Mazur uważa się za dobrego protestanta i wielu go za takiego uznaje. Dzieje się tak po części z powodu jego antypolskich i propruskich sympatii. Mazur jednak nim nie jest, ponieważ jego prostota, nawet jeśli on o tym nie wie, czyni go spokrewnionym duchowo z katolicyzmem. On nim nie jest, bo brak mu protestanckiego wykształcenia. Nie potrafi odróżnić wiary chrześcijańskiej od niechrześcijańskiej, ani protestanckiej od katolickiej. Mieszając wszystkie te elementy, znajduje swoją kościelną egzystencję $\mathrm{w}$ formach protestantyzmu. Jednak bezkrytyczność, jaką on też objawia, świadczy o tym, ze protestantyzm nie jest w nim ani wyraźnie, ani pewnie ugruntowany. ${ }^{55}$

Właśnie w tej specyficznej formie religijności, „opartej bardziej na intuicji aniżeli pełnym zrozumieniu zasad wiary, z położeniem nacisku raczej na zewnętrzne formy kultu niż wewnętrzne przeżycie wiary" ${ }^{56}$, upatrywać należy jednej z głównych przyczyn popularności rozwoju gromadek zarówno pośród Mazurów, jak i Litwinów. Wiele wskazuje na to, że przynależność do gromadek nie zmieniła nastawienia przeciętnego chłopa do spraw wiary, ani też nie pogłębiła w sposób istotny jego religijności.

We wspomnianej już powieści Los rodziny Šimoniai z Aukštujai, Simonaityte, na przykładzie jednego tylko rodu, utkała obrazek z dziejów Małej Litwy w sposób niezwykle misterny. Odnaleźć w niej można wiele warstw, chociażby autobiograficzną, bardzo rozbudowaną warstwę historyczną, społeczno-obyczajową, historyczną, mitologiczną, etnograficzną... ${ }^{57}$ Jest też w powieści osobny rozdział poświęcony jednej tylko postaci: Anskisowi Šimonisowi - gromadkarzowi, kaznodziei, który to skonfliktowany jest ze swym bratem, Jokūbasem, a to z tej przyczyny, że ten ostatni wciąż nie odciął się od pogańskich korzeni. Nie mogąc dojść z bratem do porozumienia (chciał go m.in. nawrócić, ale Jokūbas nazwał go w odpowiedzi

55 F.S. Oldenberg, op. cit., ss. 71-72.

56 G. Jasiński, Pomiędzy sekta a Kościołem, s. 21.

57 Zob. D. Pupalaigytè, Istoriškumas ir kultūriniai klodai. „Aukštujų Šimoniu likimo” žanriniai ypatumai, DARBAI ir DIENOS, 2003, nr 36, ss. 107-134. 
świnią $\left.{ }^{58}\right)$, Anskis przez nikogo niezauważony podpala jego gospodarstwo, będące jednocześnie także i jego domem rodzinnym, i umywa od tej zbrodni ręce. Ważny jest przy tej okazji zbudowany przez Simonaityte dialog gromadkarza ze świadkiem tragedii, nieznajomym wędrowcem:

- No, mógłbyś tam chociaż pomóc. Przecież i ciebie dotknęło nieszczęście!

- Ja pomóc? Nie moje świnie, nie mój bób. Sam się w to wpakował, sam niech się ratuje. Mój chlebek gotowy, stół dla mnie nakryty wszędzie, gdzie tylko pójdę.

- To nie po chrześcijańsku, - powiedział nie wiadomo kto zacz, którego nikt nie znał.

- No, jeśli chrześcijaninem byłby mój brat, byłbym i ratował, ale gdyby był chrześcijaninem, nic takiego by się nie wydarzyło.

- A może, sam podpaliłeś? - zapytał obcy, i nie czekając odpowiedzi, poszedł swoją drogą.

W scenie tej, opartej o popularny schemat mitycznego spotkania zwykłego śmiertelnika z przemierzającym ziemię, przebranym za wędrowca wszechwiedzącym bogiem, dochodzi do zerwania maski z twarzy Anskisa i ukazania jego dwulicowości. Gromadkarz został przez pisarkę przedstawiony jako człowiek na wskroś zły, zepsuty, wyrachowany i leniwy, którego w innym miejscu określa również za

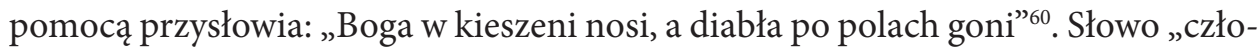
wiek” jest zresztą niewłaściwe, Anskis oburza się, gdy je słyszy, bo przecież „kaznodzieje to nie ludzie"61. Rozmyślając nad tym, co się stało, przekonany o swej wyjątkowości i nieomylności Šimonis zadaje pytanie: „Dlaczego brat mój był taki? Przez niego i mnie przyjdzie teraz bez ojcowizny po okolicy się błąkać. Tylko pouczyć go chciałem.” Narrator powieści reaguje na nie w sposób zaskakujący: „Sumienie, to prawda, ma jeszcze Anskis Šimonis"62.

Usprawiedliwić tego bohatera i dokonać rachunku jego sumienia próbowała Deimantè Pupalaigytè:

Wydaje mi się, że w tym człowieku skrywa się bunt. Najprawdopodobniej wszystko w Anskisie wynika z nieświadomości. Jego natura jest pogańska. Dopasowując się do życia chrześcijańskiego, staje się kaznodzieją. Próbuje poświęcić

\footnotetext{
I. Simonaityte, op.cit., ss. 258, s. 114

Ibidem, ss. 258, 114.

Ibidem, ss. 258, 121.

1 Ibidem.

62 Ibidem.
} 
się bogu, którego nie zna. Właśnie z tego powodu nowa wiara nie może dosięgnąć głębi serca Anskisa, dlatego też błądzi on. ${ }^{63}$

Ponownie więc pojawia się tutaj kwestia ukrywania prawdziwego ja i przybierania różnej, w zależności od okoliczności i potrzeb, tożsamości. Powyżej przytoczone fragmenty powieści Simonaitytė nie są jedynymi, w których gromadkarz pozwala sobie na grzech w chwili, gdy nikt nie patrzy albo też, gdy świadkowie danej sytuacji wykazują się dużą pobłażliwością ${ }^{64}$. Na przykładzie Anskisa zobrazowane zostały w sposób bardzo dosadny tarcia pomiędzy pogaństwem a chrześcijaństwem, konflikt żyjących zgodnie z rytmem natury chłopów z narzucającymi im swą kulturę Niemcami, a w końcu i piętrzące się z tego powodu nieporozumienia wewnątrz rodzin. Nie można nie zauważyć, że Simonaityté, podobnie jak wcześniej Balys, ma do członków gromadek ogromny żal o zrujnowanie krajobrazu kulturowego i tożsamości rdzennych mieszkańców Małej Litwy. Rodzi się pytanie, dlaczego tak szkodliwe z różnych względów gromadkarstwo było jednocześnie tak bardzo pociągające?

Członkowie ruchu, co również zauważył już Jasiński, wyróżhiający się od miennym spojrzeniem na świat, zachowaniem i strojem, zaliczani byli do tej samej grupy ludzi, co i szeptuchy, znachorzy, wiekowi starcy, przypisywano im jakieś niepoślednie cechy, wyróżniano ze społeczności, a to z kolei sprawiało, że z jednej strony budzili oni szacunek, a z drugiej - respekt i strach ${ }^{65}$. Bycie gromadkarzem musiało więc być dla niektórych niezwykle atrakcyjne, wystarczyło spełnić pewne warunki, czy choćby przybrać właściwą postawę, by zwrócić na siebie uwagę i podnieść swój status społeczny (książkowy bohater, Anskis, stawia się nawet ponad ludźmi). Wobec powyższych przykładów, niejako samoistnie nasuwa się stwierdzenie, że istotnie nie musiało się to łączyć $\mathrm{z}$ całkowitym odrzuceniem wcześniej kultywowanych, wyrosłych jeszcze z pogaństwa, tradycji.

Melchior Wańkowicz był uczestnikiem spotkania gromadkarzy we wsi Linkowa i dostrzegł w nim trzy elementy: „sekciarski pokost”, „słowiańskość, polskość, która wyłazi z tych tam wersetów, jak słoma z rozprutego siennika”, ostatni zaś to właśnie ,jak upiór głodna i nigdy karmą duchową niedokarmiona - dusza wschodnia tego ludu, dusza, której kiedyś pieśni śpiewali fulisze [sic!] i ligasze, wyrżnięci po świętych gajach"66.

W cytowanym już Roku mazurskim z roku 1925, zawarła Sukertowa kilka stwierdzeń, o które uzupełnić można spostrzeżenia Wańkowicza, Simonaitytė oraz

\footnotetext{
63 D. Pupalaigyte, op. cit., ss. 125-126.

${ }_{64}$ Por. I. Simonaitytè, op. cit., s. 258, s. 122.

65 G. Jasiński, op. cit., s. 40.

66 M. Wańkowicz, Na tropach Smętka, wyd. 3, Warszawa 1936, s. 179.
} 
szeregu folklorystów czy historyków, poczynione na przestrzeni lat, zarówno przez obcych, jak i swoich, nie tylko na wsi mazurskiej, ale i litewskiej:

Wiele z przytoczonych przez Pisanskiego ${ }^{67}$ zwyczajów przetrwało do dnia dzisiejszego w szczególności zaś w wioskach odległych od niemieckich ognisk „kultury”, w chatach słomą krytych, zdobionych rzezanami i sparagami u szczytów, pośród tajemniczych i wiecznie zieleniejących moczarów nad brzegami rozlewnych jezior. A wiara ta w przesądy ojców tak głęboko zakorzeniła się w narodzie mazurskim, że nie zdołali jej wyplenić ani Kościół niemiecko-narodowy, czyli ewangelicko-unijny, powszechny w całych Prusach, ani szkoła niemiecka, ani gadzinowe kalendarze, osławionych germanizatorów Gerssa i Hensla, wydawane od kilkudziesięciu lat w Królewcu.

$3 \sqrt{3}$ To systematyczne tępienie „zabobonów” pogańskich miało na celu wyplenienie z duszy Mazura pierwiastków rdzennie polskich. Nawet młode pokolenie w poczuciu swej kultury nabytej odnosi się z pewnego rodzaju pobłażliwością i tolerancją do zabobonów starszego pokolenia. (Niemcy ukuli przysłowie: „gdzie się kończy kultura, tam znajdziesz Mazura”).

Mroczne dni zimowe, długie wieczory, uginające się pod okiściami śniegu gałęzie strzelistych sosen i świerków oraz wycie zgłodniałych wilków, wszystko to sprzyja owej wierze w przesądy i gusła ${ }^{68}$.

Wielowiekowa niewola Mazura pruskiego, systematyczne rugowanie przez „kulturę” pruską zwyczajów rodzimych i języka ojczystego, nieprzebieranie w środkach, deprawująco wpłynęły na jego duszę, urobiły w nim nieufność i skrytość - nie zdołały jednak wykorzenić tego, co z pokolenia na pokolenie przekazywane było, rodzimy dorobek, wiarę w mądrość „starych ludzi”. Stąd zwyczaje Mazurów z krainy tysiąca jezior, ich zabobony, wiara w przepowiednie, zamknięte w przysłowiach, dziś są żywe tak, jak były przed wiekami i dawniej ${ }^{69}$.

Z całą pewnością dodać można, że wiary ojców nie zdołał wyrugować także i niezmiernie aktywny ruch gromadkarski. Litwini i Mazurzy bronili się przed jego wpływem w identyczny sposób, jak przed każdym innym zjawiskiem niosącym zmiany i zagrożenie, a więc stawali się podejrzliwi i skryci w stosunku do obcych, zachowywali pozory i dopasowywali się do danej sytuacji, by w głębi duszy pozostać wiernymi przekonaniom swych ojców. „Prawdziwy Przyjaciel Ludu”, a więc

${ }^{67}$ Jerzy Krzysztof Pisanski (1725-1790) - teolog ewangelicki, pedagog, od roku 1759 do śmierci rektor szkoły katedralnej w Królewcu, pisarz, pruski regionalista, autor m.in. Historia litteraria Prussiae (1762-1765).

68 „Rok mazurski” Emilii Sukertowej, ss. 356-357.

69 Ibidem, ss. 359-360. 
"Gazeta Lecka”, za pośrednictwem zamieszczonego w niej w roku 1887 Poematu o Gromadkach autorstwa Jana Lustiga z Małych Zawad, w Oleckowskiem, z całej siły przestrzegał przed "gromadkowymi ludźmi”, ale z drugiej strony dostrzegał przede wszystkim tę ich rozdartą, „,niedokarmioną" duszę:

1. Miałem ja przyjaciela,

Pożal się go Boże!'

Odemnie on odewstał

Do Gromadków przystał,

I z nimi żyć może.

2. Nad drugich się wynosi,

Wierzy w zamawianie,

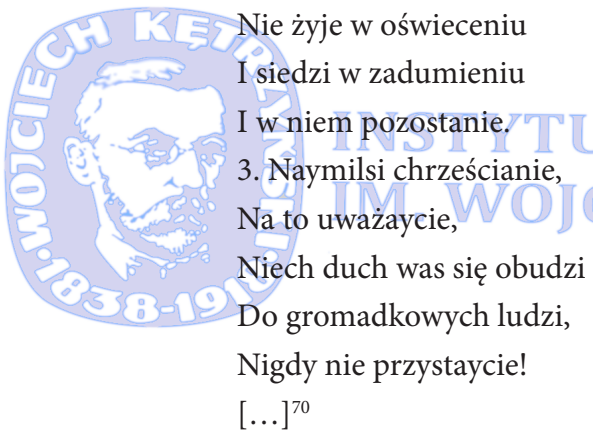

Scharakteryzowanie gromadkarza jako tego, który „wierzy w zamawianie, nie żyje w oświeceniu", nie wydaje się być przesadzone, a wręcz przeciwnie - całkiem naturalne. Prezentowane przezeń „archaiczne oddanie się wierze” odnotowane zostało przez zdecydowaną większość badaczy, nawet wówczas, gdy nie stanowiło głównego przedmiotu ich zainteresowania.

Spostrzeżenia zewnętrznych obserwatorów do pewnego stopnia uzupełnić mogą także i wzmianki, a niekiedy nawet większych rozmiarów relacje z konkretnych gmin czy powiatów, informujące o przesądności mieszkańców omawianego obszaru, które to zamieszczano w prasie, przykładowo małolitewskiej: „Tilžès keleiwis“, Lietuwiszka Ceitunga“, „Nauja Lietuwiszka Ceitunga“, „Kaimynas“, „Apzwalga“. Doniesienia dotyczyły najczęściej medycyny ludowej ${ }^{71}$ oraz sposobów

${ }_{70}$ J. Lustig, Poemat o Gromadkach, w: „Gazeta Lecka. Prawdziwy Przyjaciel Ludu”, 1887, nr 41, s. 3.

71 Zob. J. Tilvikas, Tarp religiniu, kultūriniu, socialiniu priešpriešu: lietuvininku liaudies medicina XIX-XX a. pirmoje pusèje, Logos, 2016, nr 89, ss. 184-195 - tam dalsza literatura; J. Janavičienè, Senujų lietuvininkų liaudies medicina, w: Lietuvininku kalba, ss. 83-86. Mnogość tych doniesień wynika zaś stąd, że obyczaje „odnoszące się do zwalczania chorób, miały przyczynę w ograniczonym dostępie do pomocy medycznej, lekarzy i aptek, a także drogich leków oraz ogólnego braku nawyku ich stosowania. Wiele z osób uznawanych za czarowników czy zamawiaczy zajmowało się ziołolecznictwem. Do tego dochodziło «lepsze» wizualnie i słuchowo postępowanie 
uzdrawiania zarówno ludzi, jak i zwierząt, głównie tych, na które rzucono urok, a także wciąż jeszcze powszechnej wiary w czarownice (lit. ragana) i stosowaną przez nich magię $e^{72}$. Nie może umknąć uwadze, że właśnie wiara w zamawianie i czarownice były jednym ze składników żarliwego przeżywania religijności przez Luizę Burdenski, a więc zarówno w Litwinach Pruskich, jak i Mazurach, mogły być te przekonania najgłębiej zakorzenione. O ich powszechności świadczy także i to, że w zbiorach folklorystów 2 poł. XIX i pocz. XX wieku, m.in. wspomnianego już Kalvaitisa ${ }^{73}$, a także Carla Cappellera (1840-1925) ${ }^{74}$, Kristupasa Jurkšaitisa (1852-1915) ${ }^{75}$ i innych, zajęły one stosunkowo dużo miejsca. Kalvaitis zapisał 129 wróżb, przesądów i informacji dotyczących medycyny, Jurkšaitis podał 33 przywary, a w przygotowanym do druku przez Jonasa Balysa obszernym opracowaniu $Z$ folkloru Małej Litwy (Iš Mažosios Lietuvos tautosakos) znalazło się aż 281 wróżb i przesądów ${ }^{76}$ zebranych przez licznych informatorów. Niestety, nie odnotowano przynależności informatorów do konkretnej grupy wyznaniowej, a co za tym idzie, nie wiadomo, czy którakolwiek z zarejestrowánych jednostek spisana została z ust gromadkarza.

Opracowań poświęconych obecności miejscowego folkloru w życiu wyłącznie gromadkarzy właściwie nie ma, bo przecież, zważywszy na ich światopogląd, istnieć nie powinny. $\mathrm{Na} 1959$ rok datowany jest pozostający jedynie w rękopisie zbiór pt. Tysiąc przysłów oraz powiedzeń, używanych przez szyłokarczemskich gromadkarzy, zapisanych od nich, gdy opuszczali swoja ojczyzne w latach 1957, 1958, 1959 (Tükstantis patarlių bei priežodžių, vartojamų šilutiškiu surinkiminin-

znachorów, wzmacniających siłę własnych medykamentów formułkami, zawierającymi elementy religijne obok magicznych." (G. Jasiński, Kościół na Mazurach, s. 256).

72 Np.: (Isz Lietuwos ir Prusu Prowincu.) Priewieros, Nauja Lietuwiszka Ceitunga, 1907, nr 59, s. 3 - rodzina ze wsi Puskepaliai zwróciła się o pomoc do karciarki (liet. Kortininke) z Tylży, gdyż jej krowy i konie zaczęły marnieć, a wkrótce podupadło i całe gospodarstwo; Isz Szilokarcziamos Kreizo. [Apie Priewiera], Lietuwiszka Ceitunga, 1908, nr 32, s. 3 - żona dzierżawcy odkryła, że ktoś w nocy obciął wełnę jej kozom i oskarżyła o zamówienie jej zwierząt inną gospodynię; Szilokarcziama [Dywnas Tikejjims], Tilžès Keleiwis, 1908, nr 95, s. 3 - na targu w Szyłokarczmie pewien gospodarz karmił swego zmęczonego konia chlebem, spotkał się z gniewem swego sąsiada, który należał do wierzących w pewien zabobon: „jeśli ktoś swego konia chlebem karmi, ten odbiera siłę koniowi swego sąsiada"; (Wisokia Zine.) Apie Lietuwininkû Prywieras, Tilžès Keleiwis, 1910, nr 1, s. 2 - notka zawiera m.in. takie oto stwierdzenie, dotyczące ludzi parających się czarami: „Jest to straszny grzech, za prawdę utrzymywać, że Bóg mógłby złym ludziom tę moc darować, innym szkodę czynić”; (Isz Prusu Prowincu.) Stalupénuose, Apzwalga, 1914, nr 3, s. 2 - dwie gospodynie, z podejrzeniem, że jedna drugiej zaczarowała krowy, udały się (każda z osobna) po radę do znajomego Mistrza Czarowników (lit. Raganu Mistras).

73 V. Kalvaitis, I. Pažiūrai. II. Burtai. Medicina. III. Laiškas [Užrašè (Pažiūrai) ir surinko (kita medžiaga) Mažojoje Lietuvoje XIX amžiaus pabaigoje], w: Juodoji knyga. Surinko Jonas Basanavičius, red. K. Aleksynas. Jono Basanavičiaus tautosakos biblioteka, t. 12, Vilnius 2014, ss. 53-99.

74 C. Cappeller, Kaip senëji Lëtuvininkai gyveno. Aufzeichnungen aus dem Kreise Stallupönen mit Anmerkungen und Wörterbuch von... Herausgegeben von der Litauischen literarischen Gesellschaft zu Tilsit, Heidelberg 1904.

75 K. Jurkšaitis, Pryvieros [Užrašè Ragainès (Mažoji Lietuva) apylinkèse XIX amžiaus pabaigoje], w: Juodoji knyga, ss. 40-52.

76 Iš Mažosios Lietuvos tautosakos, ss. 3-91. 
kų, užrašytu iš ju apleidžiant jiems savo tévynę 1957, 1958, 1959 metais), ułożony przez Jonasa Jurgisa Gocentasa ${ }^{77}$, lecz jego zawartość rozczarowuje. Złożyły się nań bowiem głównie aforyzmy, wyjątki z Pisma Świętego lub literatury pięknej oraz oczywiście przysłowia i powiedzenia, aczkolwiek zdecydowana ich większość jest powszechnie znana. Jedno tylko powiedzenie: „Aitvaras (kaukas) wszystkim pracowitym bogactwa nosi” (lit. „Aitvaras (kaukas) visiems darbštiesiems turtus neša”) może podpowiadać, że gromadkarze przechowali wiarę w istnienie świata nadprzyrodzonego i obecność istot mitycznych.

Rūta Grumadaitè w artykule podsumowującym wyniki organizowanych w latach 1986-1989 przez Katedrę Języka i Literatury Litewskiej ówczesnych Kłajpedzkich Fakultetów Litewskiego Konserwatorium Państwowego ekspedycji dialektologiczno-folklorystycznych w rejonie Kłajpedy i Szyłokarczmy, wynotowała, że udało się zgromadzić 70 pieśni - niestety, ledwie kilka wartościowych, 10 bajek (w tym dwie magiczne), 40 bajek etiologicznych / legend - większość z nich o charakterze mitologicznym (ich bohaterami są aitvarai czy też diabły), 5 podań, 20 przysłów i powiedzeń, 15 zagadek, 1 anegdotę, 8 zabaw w kółku, 6 objaśnień snów, 200 opowieści etnograficznych, 12 epitafiów, 15 wspomnień o działaczach kulturalno-społecznych, 2 powielone książki, 6 metryk dawnej edycji, kilka numerów "Podróżnika Litewskiego" lub jego wycinki, zdjęcia i 2 śpiewniki ewange$\operatorname{lickie}^{78}$. Zastanawiający jest fakt, że nie zapisano ani jednego zaklęcia, wróżby czy przesądu. Bez wątpienia wciąż jeszcze, podobnie jak pieśni, musiały być one przechowywane w pamięci, choć być może w 2 poł. lat 80 -tych było już zbyt późno na poszukiwanie jednostek folkloru tego rodzaju, a przede wszystkim, krajobraz kulturowy, społeczny i polityczny litewskich wsi i małych miasteczek, nie przypominał już tego z wcześniejszego okresu. Dodatkowo, należy pamiętać o słowach Grumadaitė na temat charakteru mieszkańców odwiedzanych przez nią miejscowości.

Zupełnie inny krajobraz kulturowy Małej Litwy, dużo bogatszy, udało się zbudować kilka lat wcześniej Rūcie Petkūnienè w powstałym w 1974 roku maszynopisie pracy dyplomowej pt. Zwyczaje Prusów (Małolitwinów) [Prūsu (lietuvininku) papročiai]. Na wstępie opracowania podała autorka bardzo ważną informację, która tłumaczy powodzenie jej przedsięwzięcia, mianowicie, urodziła się ona w rejonie szyłokarczemskim, zna jego mieszkańców i stąd jej zainteresowanie zwyczajami tego obszaru, które, jak zauważa, są już na wyginięciu ${ }^{79}$. Głównym celem Petkūnienè było zebranie informacji o obchodzonych w rodzinach luterańskich świętach

77 J.J. Gocentas, Tūkstantis patarlių bei priežodžių, vartojamų šilutiškių surinkimininkų, užrašytų iš jų apleidžiant jiems savo tèvynę 1957, 1958, 1959 metais, w: Surinkimininkai (Lietuvių pietistai), Šilutè 1959, LNB RS, sygn. F140-13, ss. 22-53.

78 R. Grumadaite, op. cit., ss. 35-36.

79 R. Petkūnienè, Prūsų (Lietuvininku) papročiai, Vilnius 1974, VUB RS, sygn. F85-L328, s. 24. 
kalendarzowych i kościelnych, ale udało jej się dostrzec także wiele innych szczegółów z ich codziennego życia. Bez wątpienia pośród rozmówców badaczki byli gromadkarze, ich krewni lub też wnikliwi obserwatorzy specyficznego stylu ich życia. Niejednokrotnie wymienieni zostali kaznodzieje (lit. kalbėtojai, sakytojai), a Święto Cmentarne (lit. kapiniu šventè) z ich uczestnictwem opisano bardzo szczegółowo.

Z opracowania wyłania się obraz ewangelickiej społeczności Szyłokarczmy, na której zauważalny i wyraźny ślad pozostawiła działalność gromadek. Jej życie cechuje uporządkowanie, systematyczność, podporządkowanie rytmu dnia pracy na gospodarstwie oraz wspólnej modlitwie i śpiewaniu pieśni, zarówno w domu, kościele, jak i podczas zgromadzeń i Święta Cmentarnego. O niektórych zjawiskach lub czynnościach wypowiadali się rozmówcy Petkūnienė w typowy dla gromadkarzy sposób: „brzydka rzecz” (lit. „negražus dalykas“). Pośród takich właśnie „rzeczy” znalazło się zarówno picie wina lub wódki, składanie wizyt w pierwszy dzień Świąt Wielkanocnych, jaki też rozmawianie i rozglądanie się podczas Święta Cmentarnego w chwili, gdy przemawiał kapłan. Przy okazji omawiania zwyczajów weselnych podaje zaś autorka, że jeśli uroczystośc odbywała się w domu gromadkarskiego kaznodziei, często brakowało na niej muzyki ${ }^{80}$. Ogólnie odnieść można wrażenie, że rozrywka na opisywanym przez autorkę terenie nie była zjawiskiem powszechnym. Niejednokrotnie wyróżnia autorka te momenty, kiedy radość i zabawa były nie zakazane, ale dozwolone.

Pośród takiej społeczności, na pocz. lat 70-tych wciąż jeszcze przestrzegającej, przynajmniej do pewnego stopnia, dawnych zwyczajów, udało się badaczce zapisać również kilka przesądów, związanych ze świętami kościelnymi, rodzinnymi oraz pracą na roli. Zdecydowana ich większość, znana zresztą również w innych regionach Litwy i Europy, wiąże się z cyklem wielkanocnym. Popularnym zwyczajem pierwszego dnia Wielkiejnocy było obserwowanie tańca wschodzącego słońca, które, jak pisała Sukertowa-Biedrawina, „wschodząc na Zmartwychwstanie, cieszy się ze zbawienia świata, a z radości podskakuje, niby baranek wielkanocny" ${ }^{\prime 1}$. Również słowa użyte przez Petkūnienė do jego charakterystyki są bardzo znamienne i świadczą o bardzo naturalnym i subtelnym przenikaniu się dwóch światów, pogaństwa i chrześcijaństwa, modlitwy i zabobonu: „W pierwszy dzień Wielkanocy gospodarze wstawali wraz z dziećmi wcześnie, by zobaczyć, jak wschodzące słońce tańczy. Jedni widzieli i wierzyli, inni może i nie wierzyli, że ono tańczy, milczeli tylko. Odmówiwszy później pacierze, myli się wodą ze źródełka lub rowu, szli na śniadanie" ${ }^{2}$. Podobnie na Mazurach „z pobożnym zaciekawieniem oczekują mieszkańcy wiosek [...] tego osobliwego zjawiska, witają je, padając na kolana ze

$80 \quad$ Ibidem, s. 22.

81 „Rok mazurski” Emilii Sukertowej, s. 367.

82 R. Petkūnienè, op. cit., ss. 12-13. 
słowami modlitwy Pańskiej na ustach. Po powrocie do domu skrapia gospodarz wodą, przyniesioną z rzeki, członków swej rodziny tudzież czeladź i domowników, gdyż to sprowadza błogosławieństwo, a leniwych odmienia tak dalece, że stają się pracowitymi. Po śniadaniu udaje się Mazur wraz z rodziną do pobliskiej świątyni, aby tam modlitwą gorącą i gromkim serdecznym śpiewem chwalić Przedwiecznego"s3.

Z obchodami szeroko opisanych świąt Wielkanocnych (w niektórych regionach szczególnie Wielkiego Czwartku lub Piątku) wiążą się też zabiegi mające na celu ochronienie domu przed pchłami. Petkūnienè podaje, że za zignorowanie ustalonego porządku i udanie się w gości w pierwszy dzień świąt, wyznaczano karę „odpchlenia” kożucha - „kategorycznie należało trzymać się tego zwyczaju, jeśli nie chciało się popaść w biedę"84.

Do ciekawych fragmentów opracowania należy też poczyniona przy okazji zwyczajów chrzcielnych wzmianka kobiecie której zadaniem było wniesienie dziecka do kościoła (lit. nešèja), a później przekazýwanie go z rąk do rąk, tak, by każdy z obecnych potrzymał je choć chwilę $e^{85}$. Co ważne, jeśli noworodek był podczas wypowiadania nadawanego mu imienia spokojny - mógł umrzećs ${ }^{6}$. Nie wiadomo, czy zwyczaj ten praktykowali też gromadkarze.

W pracy Petkūnienė przykłady zabobonów są nieliczne, ale zważywszy na to, że nie na nich przecież skupiała się uwaga badaczki, ich obecność odczytywać można jako świadectwo głębokiego zakorzenienia przesądów w codzienności szyłokarczemskich protestantów, a w związku z tym, musiały one, podobnie jak ludowa pieśń, należeć także i do świata gromadkarzy.

$\mathrm{Na}$ tle powyższych, skromnych informacji pochodzących z różnego rodzaju źródeł, bardzo cenna jest wypowiedź Helmuta Petrikasa ze wsi Žalgiriai, pozyskana $\mathrm{w}$ trakcie ekspedycji w sierpniu 2017 roku przez autorkę artykułu ${ }^{87}$. Babcia rozmówcy, Anna Jurgeneit z domu Bubleit (1873-1955), pochodząca z włączonej w 1949 roku do miasteczka Ruś rybackiej wsi Skirvytèlè była z jednej strony kobietą bardzo pobożną, a z drugiej - wierzyła „we wszystkie przesądy, jakie tylko istniały”. Petrikas pamięta, jak jego babcia spędzała jesienne wieczory w gronie kil-

83 „Rok mazurski” Emilii Sukertowej, s. 367.

${ }^{84}$ R. Petkūnienė, op. cit., ss. 13-14. Jedna z litewskich bajek etiologicznych podaje, że pchły stworzone zostały przez Boga (lit. Dievas) z myślą o napuszczeniu ich na Diabła (lit. Velnias). Ten zaś miał z nimi właśnie wielki kłopot - w żaden sposób nie mógł się od nich uwolnić. Przywołać w tym miejscu można również przysłowie „czepić się, jak pchła kożucha”, które odnotował m.in. Samuel Bogumił Linde w Słowniku języka polskiego w roku 1807.

85 R. Petkūniené, op. cit., ss. 22-23.

86 Ibidem, s. 23.

87 Informacje pozyskane w trakcie ekspedycji zorganizowanej w ramach projektu badawczego „Modernybès ir tradicijos sampyna: surinkimininkų judejimas Mažojoje Lietuvoje” („Splot nowoczesności i tradycji: ruch gromadkarski w Małej Litwie") w dn. 25.08.2017. Informator: Helmutas Petrikas, ur. 26.10.1932 w Skirvytėlè, gm. Smalininkai, obecnie zamieszkały w Žalgiriai, gm. Šilutè. Materiał przechowuje LKI (Lietuvių kalbos institutas). 
ku koleżanek na opowiadaniu historii, które napawały go ogromnym strachem. Uczestnikom ekspedycji opowiedziane zostały dwie z nich. Bohaterem pierwszej jest pewien mieszkaniec okręgu Kłajpedy (informator nie mógł przypomnieć sobie jego imienia i nazwiska), który nigdy nie chodził na pogrzeby. Zapytany o powód takiego zachowania, odpowiedział, że nie może w nich uczestniczyć, gdyż dostępne dla jego oczu jest to, czego nie widzą inni, a mianowicie: widzi on dusze obsiadające trumnę, a im bliżej cmentarza, tym tych dusz jest więcej. Drugą historię mieszkańcy Rusi i okolic opowiadają sobie z pokolenia na pokolenie. Wydarzyła się ona jesienią, prawdopodobnie w noc 1 listopada, a więc w noc zaduszną. Pewien człowiek wracając z Szyłokarczmy do Skirvytėlè, zauważył w kościele w Rusi delikatnie migoczące światło. Zaciekawiony wszedł do środka, a jego oczom ukazali się zmarli w takiej postaci i w takich ubraniach, jak ich pochowano. Wybiegł szybko i skierował się w stronę rzeki, na której zauważył łódkę. Poprosił, by wiosłujący przewiózł go na drugą stronę (nie było jeszcze wówczas mostu na rzece Pakalnė, który połączył Ruś i Skirvytèlè). Po jakimś czásie biedak zorientował się, że nie jest przewożony łódką, ale miękką i wilgotną trumną. Mimo wszystko jednak dotarł do domu cały i zdrowy, a przygodę, która go spotkała, poznali wszyscy okoliczni mieszkańcy. Babcia Petrikasa, Anna Jurgeneit, której bliska była działalność gromadkarzy, mocno wierzyła w każdą taką opowieść.

Przedstawiony powyżej, niewielki wycinek nieistniejącego już świata, uświadamia, jak bardzo był on złożony. Dzięki temu, że gromadkarze zdołali za jego fasadą zbudować rzeczywistość niedostrzegalną dla obcych i w dużej mierze różną od tej widzialnej na zewnątrz, udało mu się pozostać nierozpoznanym. Wydaje się, że znaczne grono gromadkarzy wierzyło w obecne w tym świecie „bajki”, a w „brzydkich rzeczach" i „grzechu” nie dostrzegało niczego złego. By nie gorszyć jednak reszty „nienawróconego” społeczeństwa i nie pokazywać mu swego podwójnego oblicza, oddzielali się od niego gromadkarze wspomnianą zasłoną, która umiejętnie maskowała między innymi właśnie ich rzeczywisty stosunek do reliktów pogańskiej przeszłości, a zwłaszcza grzesznej ludowej pieśni i zabobonu. Justyna Prusinowska, Litauische und masurische Surinkimininker gegen Aberglaube, „Märchen“ und
„schlechteDinge“

Zusammenfassung

Litauische und masurische Surinkimininker wurden von ihren Zeitgenossen als extrem fromm, ehrlich, demütig rechtschaffen oder gehorsam beschrieben. Sie sollten allen weltlichen Freuden, die sie selbst Märchen, Sünden oder hässliche Dinge nannten, fremd sein und zu ihnen gehören Singen (mit Ausschluss natürlich religiöse Lieder), Tanz, Musik und andere heidnische Relikte. Es gibt keine direkten Quellen, die die Haltung der Mitglieder die Gemeinschaftsbewegung in Bezug auf Folklore und Folklore eindeutig definieren würden, und die Materialien, die diesen von Fremde gesammelten Lebensbereich berühren, sind sehr selten und betreffen hauptsächlich 
das Volkslied. Dieser Artikel konzentriert sich auf die Frage des Vorhandenseins von Aberglauben im Leben der Menge und versucht herauszufinden, ob die öffentlich bewiesene Ablehnung des Glaubens an Aberglaube ihre wirklichen Ansichten widerspiegelte oder ob er nur als Schleier diente, für den sie das wahre Gesicht verbargen. Die Nachrichten stammen aus folkloristischen Sammlungen, Archivmaterial für wissenschaftliche Expeditionen und Fiktionen, die das Leben hauptsächlich in Kleinlitauen dokumentieren, sowie aus jüngsten Zeugen der Aktivitäten litauischer Surinkimininker. Informationen, die zu verschiedenen Zeiten und an verschiedenen Orten gesammelt wurden, sind konvergierend: Die Hingabe der Psyche, hauptsächlich Bauern, beruhte auf einer starken Grundlage des christlichen Glaubens, die mit Heidentum verbunden war, die nicht vollständig ausgerottet werden konnte und ohne die ihr Glaube nicht so stark wäre. Der Artikel wurde im Rahmen des Forschungsprojekts Modernybe ir tradicijos sampyna: surinkimininkų judejimas Mažojoje Lietuvoje (Ein Plexus der Moderne und Tradition: Surinkimininker -Bewegung in Kleinlitauen) erstellt, das vom Litauischen wissenschaftlichen Rat (Lietuvos mokslo taryba) finanziert wurde Kontrakt S-MOD-17-10.

Übersetzt von Piotr Ambroziak

Justyna Prusinowska, Lithuanian and Masurian members of the Fellowship Movement in the face of superstition, "fairy tales" and "ugly things"

\section{Summary}

Lithuanian and Masurian members of the Fellowship Movement (gromadkarze) were described by their contemporaries as extremely pious, honest, humble, righteous or obedient. They were strangers to all worldly joys, which they themselyes called "fairy tales", "sins" or "ugly things", and those things associated with them, amongst others singing (with the exclusion, of course, of religious songs), dance, music and other pagan remnants. There are no direct sources that would clearly outline the attitude of the members of the Fellowship Movement movement to folklore and people, and the materials touching this sphere of their lives collected by strangers are very scare and mainly concern folk songs. This article focuses on the issue of the presence of superstitions in the lives of people and tries to determine whether the public disapproval of superstitious beliefs reflected their real views, or whether it served only as a veil behind which they hid their real faces. This information was taken from folkloristic collections, archival materials of scientific expeditions and fiction, documenting life primarily in Lithuania Minor and from the last witnesses of the activities of Lithuanian members of the Fellowship Movement. Information gathered at different times and places is convergent: the piety of the members of the Fellowship Movement, mainly peasants, was based on a strong foundation of Christian faith entwined with paganism, which could not be completely eradicated, and without which their faith would not be as strong. The article was created within the framework of the research project "Modernybès ir tradicijos sampyna: surinkimininkų judejimas Mažojoje Lietuvoje" ("A Plexus of Modernity and Tradition: The Fellowship Movement in Lithuania Minor") financed by the Lithuanian Scientific Council (Lietuvos mokslo taryba), Contract No. S-MOD-17- 10.

Translated by Aleksander Pluskowski

Dr Justyna Prusinowska

Zakład Bałtologii

Instytutu Językoznawstwa

Wydziału Neofilologii

Uniwersytet im. Adama Mickiewicza w Poznaniu

justyna.prusinowska@amu.edu.pl 


\section{Bibliografia}

Aleknavičius Bernardas

2013 Vydūno pédomis, cz. 1, Web: http://mokslolietuva.lt/2013/02/vyduno-pedomis/ [dostęp 03.11.2018].

Basanavičius Jonas

1912 Iš krikščionijos santykiu su senovés lietuvių tikyba ir kultūra. (Prie studijos „Lietuvių kryžiai archaiologijos šviesoje"), Vilnius, ss. 55-57.

Cappeller Carl

1904 Kaip senëji Lëtuvininkai gyveno. Aufzeichnungen aus dem Kreise Stallupönen mit Anmerkungen und Wörterbuch von... Herausgegeben von der Litauischen literarischen Gesellschaft zu Tilsit, Heidelberg.

Fieldmanaitė I., Bakaitė S.

1969 Padavimai surinkti Šilutès rajone, Vilnius, VUB RS, sygn. F213-110.

Gaigalat W[ilhelm]

1904 Die evangelische Gemeinschaftsbewegung unter den preußischen Litauern. Geschichtliches und Gegenwärtiges von... Königsberg.

1905 Ewangeliszki Surinkimai Lietuwoje. Isztyrinējimai apie jû Pradzią, Augimą bey dabartinị Buwį, Priekulè.

Gocentas Jonas Jurgis

1959 Tükstantis patarlių bei priežodžių, vartojamų šilutiškiu surinkimininku, užrašytų iš jų apleidžiant jiems savo tèvynę 1957, 1958, 1959 metais, w: Surinkimininkai (Lietuviu pietistai), Šilutè, LNB RS, syğn. F140-13, ss. 22-53.

\section{Grigas Kazys}

1998 Ką išsaugojo Vilius Kalvaitis, w: Prūsijos lietuvių dainos. Surinko Vilius Kalvaitis [faksimilinis leidinys], red. K. Aleksynas, Vilnius, ss. VII-XX.

Grumadaitė Rūta

1994 Klaipėdos krašto tautosakinè situacija (Pagal paskutiniujų ekspediciju medžiaga), w: Lietuvininkų kalba. Mažosios Lietuvos tautosaka. Mažosios Lietuvos etnografija. Mokslinés konferencijos pranešimai, Kaunas, ss. 35-37.

Iš Mažosios Lietuvos...

1937 Iš Mažosios Lietuvos tautosakos / Folk-lore from Lithuania Minor. Surinko J. Banaitis, J. Bruožis, D. Jagomastas, E. Jankute, A. Vilmantienè ir kt., red. J. Balys, w: Tautosakos darbai, t. III, Kaunas, ss. 3-93.

Ištraukos

1999 Ištraukos iš Viliaus Kalvaičio „Dienknygǔ“. Parenge I. Žilienè, w: „Tautosakos darbai”, t. XI(XVIII), ss. $162-187$.

Janavičienė Janina

1994 Senujų lietuvininku liaudies medicina, w: Lietuvininkų kalba. Mažosios Lietuvos tautosaka. Mažosios Lietuvos etnografija. Mokslinès konferencijos pranešimai, Kaunas, ss. 83-86.

Jasiński Grzegorz

1996 Uźródeł gromadkarstwa. O grupie „świętych” na Mazurach”, Komunikaty Mazursko-Warmińskie, nr 3, ss. 369-377.

1999 Pomiędzy sektą a Kościołem. Gromadkarze litewscy i mazurscy w XIX wieku (do 1885 roku), Komunikaty Mazursko-Warmińskie, nr 1, ss. 17-42.

2003 Kościót ewangelicki na Mazurach w XIX wieku (1817-1914), Olsztyn.

2013 Apie liuteronybès diferenciaciją Rytų Prūsijoje. Pastabos dèl surinkimų Mozūrijoje XVIII a. pabaigoje - XIX a. pradžioje, Acta Historica Universitatis Klaipedensis: Kristijono Donelaičio epochos kultūrinés inovacijos, nr XXVI, ss. 135-147. 
2014 Neopietyzm a postawy narodowe. Ruch gromadkarski na Mazurach w XIX i XX w. (do 1956). Czesść I, w: Gdański Rocznik Ewangelicki, vol. VIII, ss. 108-134.

Jurkšaitis Kristupas

2014 Pryvieros [Užrašè Ragainès (Mažoji Lietuva) apylinkèse XIX amžiaus pabaigoje], w: Juodoji knyga. Surinko Jonas Basanavičius, red. K. Aleksynas. Jono Basanavičiaus tautosakos biblioteka, t. 12, Vilnius, ss. 40-52.

Kalvaitis Vilius

2014 I. Pažiūrai. II. Burtai. Medicina. III. Laiškas [Užrašè (Pažiūrai) ir surinko (kita medžiaga) Mažojoje Lietuvoje XIX amžiaus pabaigoje], w: Juodoji knyga. Surinko Jonas Basanavičius, red. K. Aleksynas. Jono Basanavičiaus tautosakos biblioteka, t. 12, Vilnius, ss. 53-99.

Kalwaitis W.

1910 Lietuwiszkų Wardų Klètele su 15000 wardų... Surinko 1888-1894 m. ir iszleido W. Kalwaitis, Tilžè.

Kisielunaite Dalia

[1994] Senuju baltiškuju papročiu pédsakai lietuvininkų šventèse, w: Lietuvininkų kalba. Mažosios Lietuvos tautosaka. Mažosios Lietuvos etnografija. Mokslinių konferenciju pranešimai, Kaunas, ss. 74-76.

Klaipèdiškių dainos

1908 Klaipédiškių dainos. Surinko Jons Pakalniškis [A. Bruožis], Vilnius.

Lej(y)k-Różý́ski Fryderyk

1937 Zrzeszenia gromadkarskie wśród Mazurów, zamieszkatych na Mazowszu Pruskim, Nadrenii i Westfalii, Przegląd Ewangelicki, $\mathrm{nr}$ 8, ss. 70-71, nr 9, ss. 80-81, nr 10, ss. 88-89, nr 11, ss. 101-102, nr 12, ss. 111 114.

Lustig Jan

1887 Poemat o Gromadkach, „Gazeta Lecka. Prawdziwy Przyjaciel Ludu”, nr 41, s. 3.

Merkelis A.

1953 Iš Vydūno vaikystès ir jaunystès, Aidai, nr 4, ss. 159-162, Web: http://www.aidai.eu/index.php?option=com_content\&view=article\&id=5724:pa\&catid=345:4-balandis\&Itemid=387 [dostęp: 03.11.2018].

Oldenberg Friedrich Salomo

2000 Przyczynki do poznania Mazur. Sprawozdanie dla Centralnego Komitetu do Spraw Misji Wewnętrznej, przeł. M. Szymańska-Jasińska, oprac. i wstęp G. Jasiński, Warszawa.

Otello Ryszard

1976 Ruch gromadkarski w Prusach Wschodnich w latach 1848-1914, Komunikaty Mazursko-Warmińskie, nr 3 , ss. 307-328.

1977 „Głos Ewangelijny” (1925-1939), Komunikaty Mazursko-Warmińskie, nr 1, ss. 81-90.

1978 Obchody żniwne na Mazurach, Komunikaty Mazursko-Warmińskie, nr 2, ss. 263-278.

Petkūnas Darius, Žemaitaitis Algirdas

2009 surinkimininkai, maldininkai, w: Mažosios Lietuvos Enciklopedija, t. 4, red. V. Bagdonavičius, D. Valentukevičienè, V. Kaltenis, Vilnius, ss. 359-360.

Petkūnienè Rūta

1974 Prūsų (Lietuvininkų) papročiai, Vilnius, VUB RS, sygn. F85-L328.

Petrošienè Lina

2001 Klaipédos krašto XX a. antrosios pusés liaudies dainu pateikejai ir kai kurios jų dainu melodiju ypatybès, w: Vakarų Lietuvos muzika (I). Žurnalo „Tiltai” priedas nr. 7. Mokslo darbai, red. S. Vaitekūnas, Klaipėda, ss. 28-35. 
Prusijos

1905 Prusijos Lietuvių dainos. Surinko ir pridedamas anas per Rėzą, Nesselmann’ą, Dr. Sauerwein’ą bei kitus rinktas arba sutaisytas dainas išleido savo paties kašta Vilius Kalvaitis, Tilžè.

Pukis Jokūbas

2009 Abipus rubežiaus. II d., http://www.silaine.lt/2009/2009-10-06/Pukio_prisiminimai_IId-19.htm [dostęp: 03.11.2018].

Pupalaigytė Deimantė

2003 Istoriškumas ir kultūriniai klodai. „Aukštųų Šimonių likimo” žanriniai ypatumai, DARBAI ir DIENOS, nr 36, ss. 107-134.

Rhesa L.J.

1825 Dainos oder Litthauische Volkslieder gesammelt, übersetzt und mit gegenüberstehendem Urtext herausgegeben von..., Königsberg.

„Rok mazurski”

2004/2005 „Rok mazurski” Emilii Sukertowej. Tekst opracował, wstępem, komentarzem i przypisami opatrzył Zbigniew Anculewicz, Mrągowskie Studia Humanistyczne. Pismo poświęcone historii i literaturze w regionie mazurskim, t. 6-7, ss. 353-377.

Simonaitytè Ieva

1976 Aukštujų Šimonių likimas. Romanas, Vilnius.

Somplatzki Herbert

2001 Wiara mojej babci - sprawozdanie z zatopionego świata, w: Ewangelicy na Warmii i Mazurach. Dzieje i współczesność. Praca zbiorowa, red. E. Kruk, Olsztyn, ss. 53-54.

Sukertowa-Biedrawina Emilia

1950 Zagadnienie gromadkarstwa na Mazurach (Przyczynek do dziejów „gromadek”), Przegląd Zachodni, nr 9-10, ss. 272-283.

Tilvikas Jonas

2016 Tarp religiniu, kultūrinių, socialinių priešpriešų: lietuvininkų liaudies medicina XIX-XX a. pirmoje pusejje, Logos, nr 89, ss. 184-195.

Wańkowicz Melchior

1936 Na tropach Smętka, wyd. 3, Warszawa.

Žemaitaitis Algirdas

2003 klimkiškiai, klimkènai, Senasis surinkimas, w: Mažosios Lietuvos Enciklopedija, t. 2, red. V. Pèteraitis, Z. Zinkevičius, M. Purvinas, Vilnius, ss. 233-235.

\section{Skróty}

VUB RS - Vilniaus universiteto bibliotekos Rankraščių skyrius

LNB RS - Lietuvos nacionalinės Martyno Mažvydo bibliotekos Rankraščių skyrius. 